\title{
Strain, deformation temperatures and vorticity of flow at the top of the Greater Himalayan Slab, Everest Massif, Tibet
}

\author{
R. D. LAW ${ }^{1}$, M. P. SEARLE ${ }^{2} \&$ R. L. SIMPSON ${ }^{2}$ \\ ${ }^{1}$ Department of Geological Sciences, Virginia Tech., Blacksburg,VA 24061, USA (e-mail: rdlaw@vt.edu) \\ ${ }^{2}$ Department of Earth Sciences, Oxford University, Oxford OX1 3PR, UK
}

\begin{abstract}
This paper presents quantitative data on strain, deformation temperatures and vorticity of flow at the top of the Greater Himalayan Slab. The data were collected from the Tibetan side of the Everest Massif where two low-angle normal faults bound the upper surface of the Greater Himalayan Slab, the earlier and structurally lower Lhotse Detachment and the later and structurally higher Qomolangma Detachment. Greenschist- to sillimanite-grade quartz-rich metasedimentary rocks exposed in the Rongbuk to North Col region of the Everest Massif are characterized by cross-girdle quartz $c$-axis fabrics indicating approximate plane strain conditions. Fabric opening angles progressively increase with depth beneath the overlying Lhotse Detachment, and indicate progressively rising deformation temperatures of $525-625 \pm 50{ }^{\circ} \mathrm{C}$ at depths of $300-600 \mathrm{~m}$ beneath the detachment. Deformation temperatures of $c .450{ }^{\circ} \mathrm{C}$ are indicated by fabric opening angles in epidote amphibolite-facies mylonites located closer to the overlying detachment. A top down-to-thenorth (normal) shear sense is indicated by the asymmetry of microstructures and $c$-axis fabrics, but the degree of asymmetry is low at distances greater than $400 \mathrm{~m}$ beneath the detachment, and sillimanite grains are drawn into adjacent conjugate shear bands but still appear pristine, indicating that deformation occurred at close to peak metamorphic temperatures. These 'quenched' fabrics and microstructures indicate rapid exhumation in agreement with previous isotopic dating studies. Mean kinematic vorticity numbers $\left(W_{\mathrm{m}}\right)$ were independently calculated by three analytical methods. Calculated $W_{\mathrm{m}}$ values range between 0.67 and 0.98 , and indicate that although a simple shear component is generally dominant, particularly in greenschist-facies mylonites located between the Lhotse and overlying Qomolangma detachments, there is also a major component of pure shear in samples located at $400-600 \mathrm{~m}$ beneath the Lhotse Detachment (pure and simple shear make equal contributions at $W_{\mathrm{k}}=0.71$ ). Our integrated strain and vorticity data indicate a shortening of $10-30 \%$ perpendicular to the upper surface of the Greater Himalayan Slab and confirm that the upper surface of the slab is a 'stretching fault' with estimated down-dip stretches of $10-40 \%$ (assuming plane strain deformation) measured parallel to the flow plane-transport direction.
\end{abstract}

Keywords: Himalayas, Mount Everest, exhumation, petrofabrics, strain, vorticity.

Within the central-eastern sector of the Himalayan orogen the highest-grade metamorphic rocks are exposed in the Greater Himalayan Slab, a 20-30 km thick north-dipping tectonic unit of mid-crustal rocks (Fig. 1). The slab is bounded along the base by the south-directed Main Central thrust, and along the top by the South Tibetan Detachment System of north-directed normal faults, which separate the metamorphic and anatectic core of the Himalaya from unmetamorphosed rocks of the Tibetan plateau (Fig. 2). Beginning in Early Miocene time, southward extrusion of the Greater Himalayan Slab has had a profound influence on the geological and geomorphological evolution of the Himalaya (Hodges et al. 2001). The regional-scale geometries of the thrust and normal faults bounding the slab are now reasonably well known, and much work has been carried out on documenting shear-sense indicators along the upper and lower surfaces of the slab and constraining the early stage $P-T-t$ paths of rocks within the slab.

However, critically important gaps remain in our understanding of both the kinematics (vorticity) of flow and relationships between flow and progressive exhumation within the extruding slab. Determining the spatial and temporal relationships between timing and magnitude of displacement along the slab-bounding faults, and the kinematics of flow within the evolving slab, is crucial to our understanding of the crustal thickening, exhumation and erosional history of the orogen. For example, is flow throughout the slab dominated by simple shear (e.g. Grujic et al. 1996) or is the interior of the slab dominated by pure shear deformation and the slab bounded by stretching faults (e.g. Grasemann et al. 1999; but see also channel flow models by Grujic et al. 1996, 2002; Beaumont et al. 2001)? Identification of a pure shear component is critically important because operation of a significant pure shear component would result in: (1) thinning and dip-parallel extension of the slab itself; (2) relative to strict simple shear, an increase in both strain rates and extrusion rates. Only one published quantitative vorticity analysis has been made along a basal section of the Greater Himalayan Slab (Grasemann et al. 1999), and no such studies have previously been undertaken for the upper-middle sections of the slab.

In this paper we present new quantitative data on strain, deformation temperatures and vorticity of flow at the top of the Greater Himalayan Slab. The data were collected from the Tibetan side of the Everest Massif, where two low-angle normal faults bound the upper surface of the Greater Himalayan Slab, the earlier and structurally lower Lhotse Detachment and the later and structurally higher Qomolangma Detachment (Searle 1999a). These data complement a companion study by Searle et al. (2003) of the structural geology, thermobarometry and geochronology of the Greater Himalayan Slab in the Everest region. 


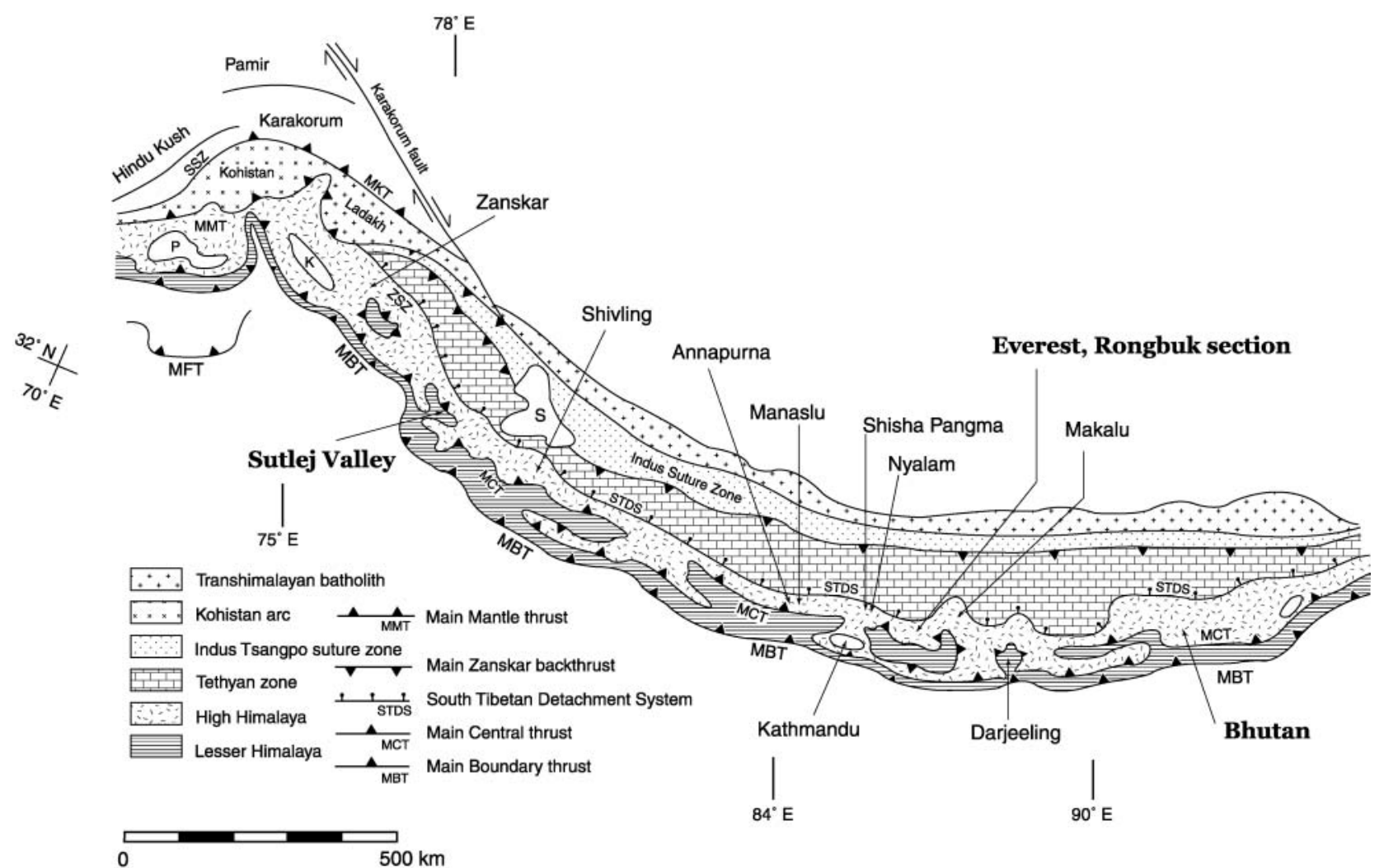

Fig. 1. Geological map of the Himalaya showing main areas discussed in text; adapted from Searle et al. (2003). The Greater Himalayan Slab (High Himalaya) is bounded below by the Main Central thrust and above by the South Tibetan Detachment System. K, Kashmir Neogene basin, P, Peshawar basin; S, Sutlej basin; SSK, Shyok suture zone; ZSZ, Zanskar shear zone.

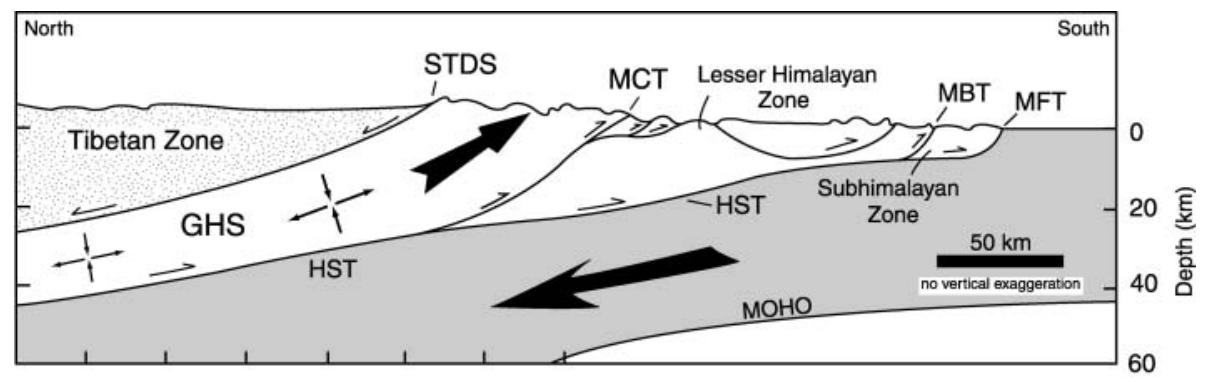

Fig. 2. Generalized cross-section through the Himalaya and southern part of Tibetan Plateau showing principal tectonostratigraphic zones; adapted from Hodges et al. (2001). Greater Himalayan Slab (GHS) is bounded above by the South Tibetan Detachment System (STDS) and below by the Main Central thrust (MCT). MBT, Main Boundary thrust; MFT, Main Frontal thrust; HST, Himalayan Sole thrust.

\section{Tectonic framework}

The Himalaya have been under continuous north-south shortening since the time of India-Asia collision at c. 54-50 Ma (e.g. Searle et al. 1987; Rowley 1998). Crustal shortening and thickening resulted in Late Eocene to Early Miocene regional Barrovian-series metamorphism, culminating in a widespread phase of crustal melting along what is now the High Himalaya (Fig. 1) during the early-mid-Miocene. The highest-grade metamorphic rocks are exposed in the Greater Himalayan Slab, a 20-30 km thick tectonic unit (Fig. 2) composed of migmatites, leucogranites and medium-high-grade rocks metamorphosed at 14-56 km depth (4-16 kbar pressure) at 35-15 Ma (see review by Hodges 2000). Within the slab, leucogranites of Late Oligocene to Miocene age were produced at pressures of 4$5 \mathrm{kbar}$ and temperatures of $c .650-750{ }^{\circ} \mathrm{C}$ (see reviews by
Pognante 1993; Searle 1996). U-Th-Pb data indicate that not all Himalayan leucogranites were produced during a single anatectic event, but instead represent melting over as much as $12 \mathrm{Ma}(c$. 25-13 Ma). During much of this time interval the source region experienced rapid decompression as a result of removal of up to $15 \mathrm{~km}$ of overburden by tectonic denudation, and erosion at rates sometimes approaching $1.0 \mathrm{~cm} \mathrm{a}^{-1}$ (Hodges et al. 1998). The highest topography $(8800 \mathrm{~m})$ and deepest erosion (5000-6000 m valleys) along the Himalaya coincide with the upper part of the slab (Hodges et al. 2001).

Traced eastwards from India through Nepal and Bhutan, the Greater Himalayan Slab extends for some $3000 \mathrm{~km}$ along strike, and is $20-100 \mathrm{~km}$ wide in plan view (Fig. 1). Throughout the central-eastern sector of the Himalayan orogen, the slab is bounded along the base by the Main Central thrust, a south- 


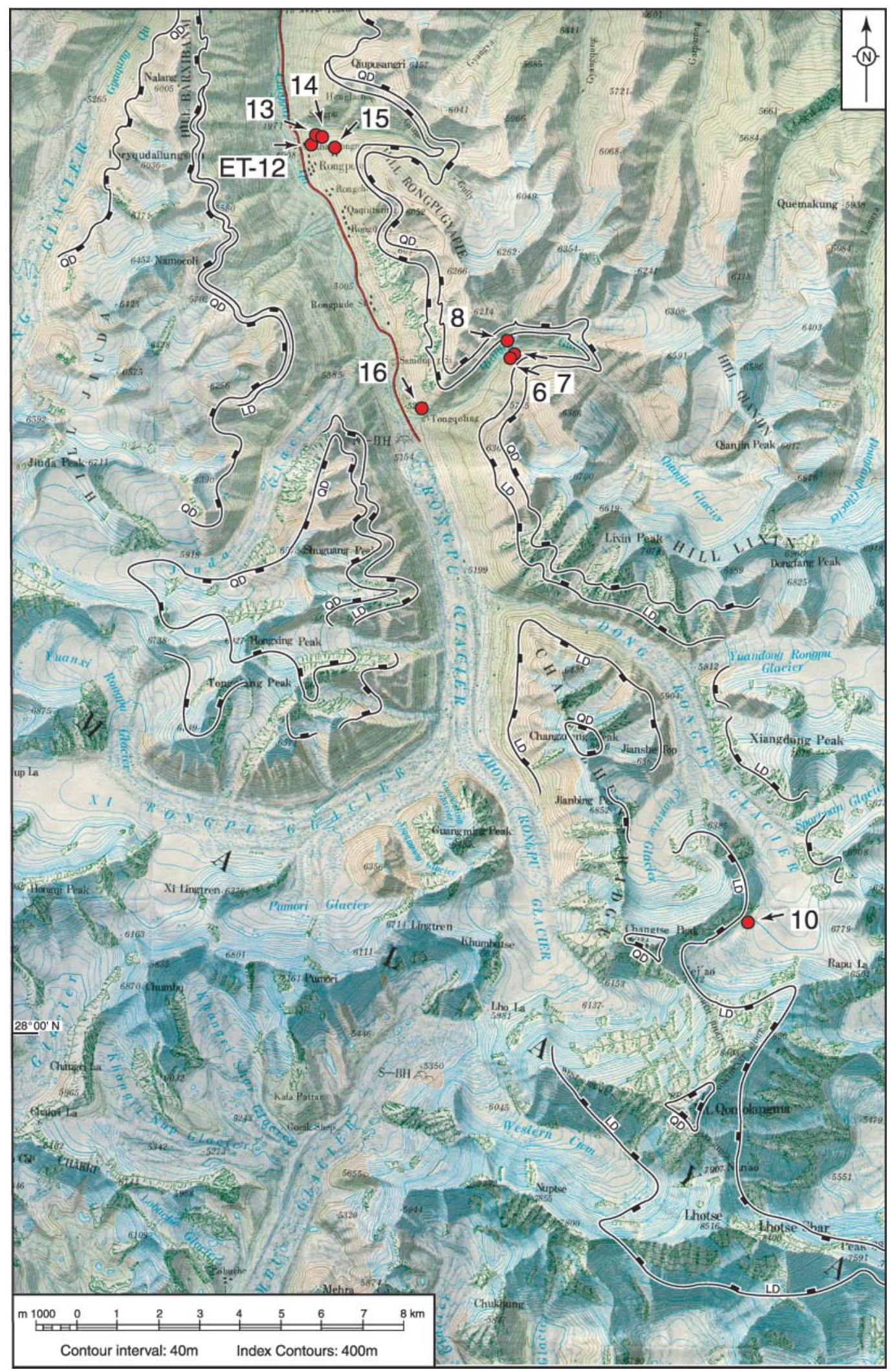

Fig. 3. Sample locations. In situ samples were collected on the east side of Rongbuk Valley above the monastery (ET-12 to ET-15) and in Hermit's Gorge (ET-6 to ET-8 and ET-16). Positions of the Qomolangma Detachment (QD) and Lhotse Detachment (LD) are taken from Searle (2003) and Searle et al. (2003). Samples were also collected from talus piles at $c .1 \mathrm{~km}$ south of ET-12 at Rongbuk Monastery (TI-5) and at Advance Base Camp beneath North Col-Changtse Ridge (ET-10); sample TI-5 is thought to have been eroded from immediate footwall to Lhotse Detachment, sample ET-10 is thought to have been eroded from hanging wall to Lhotse Detachment (see text for discussion). Base map taken from 1:100 000 Mount Qomolangma (Sagarmatha) topographic map published (1991) by the Xi'an Cartographic Publishing House. 
directed zone of intense shearing associated with characteristic inverted metamorphic isograds (Gansser 1964). The top of the slab is bounded by the South Tibetan Detachment System of orogen-parallel north-directed normal faults, which separate the metamorphic and anatectic core of the Himalaya from the essentially unmetamorphosed Tethyan passive margin sedimentary sequence to the north (Burg 1983; Burg et al. 1984; Herren 1987; Burchfiel et al. 1992).

Structural studies and geochronology indicate that thrusting and normal faulting on the margins of the Greater Himalayan Slab are broadly synchronous (Burchfiel et al. 1992; Hodges et al. 1992, 1998; but see also Murphy \& Harrison 1999). Both thrust and normal faults initiated synchronously with Miocene prograde metamorphism and melting, and have moved episodically since then. Some major fault movement clearly post-dates peak metamorphism, as shown by the inversion of earlier formed metamorphic isograds along the Main Central thrust zone and the omission of parts of the section across normal faults at the top of the slab. Marking the topographic break between the high Himalayan ranges and their foothills for more than $1000 \mathrm{~km}$ along strike (Gansser 1964), the Main Central thrust system has had a long history of movement, and estimates of cumulative reverse-sense slip range between a minimum of several tens of kilometres and a maximum of $150-250 \mathrm{~km}$ (Brunel \& Kienast 1986). The earliest fault-related fabrics on the Main Central thrust are coeval with 21-23 Ma amphibolite-facies metamorphism of hanging-wall rocks (Hubbard \& Harrison 1989; Hodges et al. 1996), but there is geochronological evidence for further displacement as recently as a few million years (e.g. Harrison et al. 1997; Hodges 2000; Catlos et al. 2002).

Quantitative constraints on minimum normal-sense dip-slip displacement are available for three strands of the South Tibetan Detachment System. In Zanskar (Fig. 1) cumulative normalsense displacement on the South Tibetan Detachment System has been estimated at $40-60 \mathrm{~km}$, based on juxtaposition of highgrade metamorphic rocks against essentially unmetamorphosed Tethyan sedimentary rocks, and assuming originally horizontal isograds and an original northward dip of $20-30^{\circ}$ on the South Tibetan Detachment System (Dèzes et al. 1999; Searle et al. 1999; Walker et al. 1999). To the north of Everest minimum dipslip displacement on the South Tibetan Detachment System was estimated at 35-40 km (Burchfiel et al. 1992; Hodges et al. 1998), and may have exceeded 90-100 km (Searle et al. 2002, 2003). In the eastern Himalaya of Bhutan structural overlap between the Tethyan sedimentary rocks and the Greater Himalayan Slab (Grujic et al. 2002) suggests minimum normal-sense displacements of $>140 \mathrm{~km}$. At least in the Everest area structurally lower ductile strands of the South Tibetan Detachment System were active at $18-16 \mathrm{Ma}$, and the upper brittle strands were active at less than $16 \mathrm{Ma}$ (Searle et al. 2002, 2003; see also Hodges et al. 1998; Murphy \& Harrison 1999).

\section{Geology of the Rongbuk-Everest area}

Pioneering geological work on Everest was carried out by Heron (1922), Odell (1925, 1948), Wager (1934, 1965) and Lombard (1958) during mountaineering expeditions on the north (Tibetan) side of the mountain. The stratigraphy of the sedimentary rocks on the north side of Everest was studied by Wang \& Zhen (1975) and Yin \& Kuo (1978). The northern side of Everest along the Rongbuk glacier was mapped by Burchfiel et al. (1992) and Hodges et al. (1992), who identified the Qomolangma Detachment, a ductile-brittle fault zone separating unmetamorphosed limestones of Ordovician age (Wang \& Zhen 1975; Yin \& Kuo
1978) above from sillimanite-grade gneisses (Rongbuk Formation of Yin \& Kuo 1978), migmatites and leucogranites below. The Qomolangma Detachment has been mapped along the Rongbuk Valley and has been traced up the northern flank of Everest to just below the summit, dipping at $5-15^{\circ} \mathrm{NE}$ (Fig. 3) (Burchfiel et al. 1992; Hodges et al. 1998; Searle 1999a, 2003; Searle et al. 2002, 2003). Nowhere along the trace of the Qomolangma Detachment can footwall rocks be matched with hanging-wall rocks and an absolute minimum of $34 \mathrm{~km}$ of dip-slip displacement has been proposed (Burchfiel et al. 1992). Pognante \& Benna (1993) and Carosi et al. (1998) mapped only one normal fault, corresponding to the Qomolangma Detachment, but Lombardo et al. (1993) identified two major low-angle normal faults, the upper fault separating unmetamorphosed Ordovician limestones from underlying upper greenschist-facies metasedimentary rocks, and the lower fault separating these rocks from high-grade gneisses of the Greater Himalayan Series (or Rongbuk Formation) containing sillimanite, cordierite and staurolite. The greenschist-facies rocks were originally named the Everest Series by Wager $(1934,1965)$ but have also been referred to as the North Col Formation (Yin \& Kuo 1978; Lombardo et al. 1993; Carosi et al. 1998).

On the Nepalese side of Everest the base of this greenschistfacies unit was interpreted by Searle $(1999 a, 2003)$ as marking the position of a major normal fault, the Lhotse Detachment (see Fig. 3). On the Tibetan side, Carosi et al. (1998) regarded the base of the Everest Series greenschists as being a broad shear zone extending for at least $1 \mathrm{~km}$ downwards into the underlying high-grade gneisses; this zone of shearing was referred to as the Qomolangma shear zone by Murphy \& Harrison (1999). Traced down-dip to the north the Qomolangma Detachment appears to cut across the underlying greenschist-facies unit, placing unmetamorphosed Tethyan sedimentary rocks directly onto sillimanitegrade gneisses and leucogranite sills and dykes. Microstructural shear-sense indicators confirming a top-to-the-north (i.e. normal) shear sense have been recorded within both the wedge of greenschist-facies metasedimentary rocks (Carosi et al. 1998) and the underlying gneisses and leucogranites (Burchfiel et al. 1992; Carosi et al. 1998). No assessment of strain path (e.g. simple v. pure shear) however, was reported in either of these studies.

Both the gneisses and leucogranites are strongly foliated and lineated adjacent to the overlying Qomolangma Detachment and Lhotse Detachment fault zones (Burchfiel et al. 1992; Carosi et al. 1998). Gneisses and schists in the footwall to the Lhotse Detachment have undergone a two-phase metamorphic history, with peak Barrovian metamorphism at c. $32 \mathrm{Ma}$, and a later high-temperature, low-pressure $\left(620^{\circ} \mathrm{C}, 4 \mathrm{kbar}\right)$ amphibolitefacies event at c. 20-22 Ma (Hodges et al. 1992, 1998; Simpson et al. 2000), and possibly continuing until c. $17 \mathrm{Ma}$ (Hodges et al. 1998). Two sets of leucogranite sills and dykes occur in the cliff section between Rongbuk Monastery and Base Camp. An earlier set of sills are foliation-parallel and contain a deformation fabric that is parallel to the enclosing gneisses, whereas a later set of dykes cross-cut the ductile fabrics in the gneisses. Traced to the north these later dykes are in turn truncated by brittle fault motion on the overlying Qomolangma Detachment. No leucogranite intrusions have been recorded within the wedge of Everest Series greenschists located between the Qomolangma and Lhotse detachments (Murphy \& Harrison 1999; Searle 1999a,b).

High-temperature $\left(>450-500{ }^{\circ} \mathrm{C}\right)$ deformation microstructures in the mylonitic leucogranites probably indicate that they were intruded during top down-to-the-north shearing (Carosi et al. 
1998; Law et al. 2001; Searle et al. 2003). U-Pb and $\mathrm{Th}-\mathrm{Pb}$ dating of monazite, zircon and xenotime from both mylonitic and undeformed leucogranites (Hodges et al. 1998; Murphy \& Harrison 1999) yield ages of 16-17 Ma, and Hodges et al. (1998) have reported ${ }^{40} \mathrm{Ar} /{ }^{39} \mathrm{Ar}$ dates of $16.37 \pm 0.04 \mathrm{Ma}$ on magmatic muscovite (see also Wager 1965; Villa et al. 1998), constraining the minimum crystallization age of the leucogranites. The minimum age of ductile shearing along the Lhotse Detachment is therefore constrained very precisely at $c .17 \mathrm{Ma}$, earlier than the late cross-cutting dykes, whereas the age of brittle faulting along the overlying Qomolangma Detachment must be younger than $16 \mathrm{Ma}$. No isotopic data are currently available on timing of greenschist-facies metamorphism in the Everest Series metasedimentary rocks located between the Qomolangma Detachment and Lhotse Detachment fault zones.

\section{Microstructures and quartz c-axis fabrics}

Oriented samples of mylonitic leucogranite and amphibolitefacies Rongbuk Formation gneiss and schist were collected in vertical sections up the east side of the Rongbuk Valley at the monastery (altitudes of 5100-5450 m) and Hermit's Gorge $(5320-5600 \mathrm{~m})$. The positions of these sections are indicated in Figure 3 . We were unable to directly sample at higher altitudes either amphibolite-facies rocks located immediately beneath the Lhotse Detachment or Everest Series greenschist-facies tectonites located above the Lhotse Detachment (as mapped by Searle 2003; see also Searle et al. 2003). However, we were able to collect unoriented samples eroded from these positions (samples TI-5 and ET-10, respectively). All microstructural and crystal fabric data are reported for sections cut perpendicular to foliation and parallel to lineation. For oriented samples these data are viewed towards the east such that a top down-to-the-north (i.e. normal-sense motion) is indicated by a sinistral shear sense. For convenience, unoriented samples are also viewed such that their asymmetric microstructures indicate a sinistral shear sense. Below we describe the mineral assemblages, microstructures and quartz $c$-axis fabrics of the samples collected, starting with the samples from the highest altitude and then progressively working to deeper structural levels.

\section{Everest Series}

Only one high-altitude sample was collected from the Everest Series. Sample ET-10 is an upper greenschist (biotite-grade) interlayered pelite-psammite (original altitude $>7000 \mathrm{~m}$ ) collected from a talus pile at Advanced Base Camp beneath the North Col-Changtse Ridge (Fig. 3). The rock is foliated and weakly lineated, and composed of elongate $(150 \mu \mathrm{m} \times 50 \mu \mathrm{m})$ plastically deformed quartz grains set in a muscovite-biotite matrix. Rhomb-shaped strongly pleochroic biotite porphyroclasts $(250-300 \mu \mathrm{m})$ occur throughout the matrix (Fig. 4a). Foliationparallel quartz veins are cross-cut and extended along microfaults (Fig. 4b), the sense of offset indicating the same shear sense as indicated by the biotite rhombs (or 'fish'). These microfaults extend into the surrounding quartz-muscovite-biotite matrix as an extensional crenulation cleavage defining incipient shear bands. Within the matrix these shear bands form a conjugate set with less well-developed shear bands and extensional crenulations dipping in the opposite direction. Deformation bands and undulose extinction are common within the veins. Boundaries between adjacent quartz grains are locally lobate, indicating grain boundary bulging (possibly under low-temperature Regime 1 recrystallization conditions as defined by Hirth \&
Tullis 1992). Quartz c-axes measured on the elongate quartz grains and quartz veins define a weakly developed cross-girdle fabric, the dominant girdle being oriented perpendicular to the prominent shear bands (Fig. 5a).

\section{Rongbuk Formation and leucogranites}

Sample TI-5 is a mylonitic epidote amphibolite-facies schist collected from a talus pile $300 \mathrm{~m}$ to the SE of the Rongbuk Monastery; as discussed below, this sample has presumably been eroded from immediately beneath the Lhotse Detachment. Foliation in TI-5 is defined by ribbons of polycrystalline quartz, which anastomose around equant-elongate hornblende, calcic pyroxene (?augite) and feldspar porphyroclasts. Shear bands (extensional crenulation cleavage) are pervasively developed throughout the rock, and hornblende and feldspar porphyroclasts display asymmetric recrystallized tails that curve towards enveloping shear bands (Fig. 4c). In more quartz-rich layers asymmetric muscovite porphyroclasts indicate the same shear sense as the shear bands, and the larger feldspar porphyroclasts are locally either forward or backward rotated (i.e. with or against the shear sense indicated by shear bands, respectively). Assuming no significant mechanical interaction between adjacent porphyroclasts, these backwardrotated porphyroclasts indicate a component of pure shear during deformation (Simpson \& De Paor 1993, 1997). Strong undulose extinction is developed only in the smaller $(<100 \mu \mathrm{m})$ feldspar grains, whereas cracking is dominant in the larger grains. Quartz has locally recrystallized by either subgrain rotation or grain boundary migration (i.e. transitional between Regime 2 and higher-temperature Regime 3 recrystallization conditions of Hirth \& Tullis 1992). Within the quartz ribbons elongate dynamically recrystallized quartz grains display a preferred alignment $\left(\mathrm{S}_{\mathrm{b}}\right)$ that is oblique to foliation $\left(\mathrm{S}_{\mathrm{a}}\right)$; the obliquity between $S_{a}$ and $S_{b}$ indicates the same shear sense as indicated by all other microstructural indicators. Quartz $c$-axes measured from polycrystalline ribbon grains in TI-5 define a Type 1 cross-girdle fabric (Lister 1977) whose sense of asymmetry with respect to foliation and lineation (Fig. 5b) also indicates the same shear sense as indicated by all microstructures.

In agreement with the findings of Burchfiel et al. (1992) and Carosi et al. (1998), the dominant microstructural shear-sense indicators in our oriented amphibolite-facies Rongbuk Formation samples (extensional shear bands, porphyroclast tails, mica fish) collected in situ from the Rongbuk Monastery and Hermit's Gorge traverses (Fig. 3) indicate a top down-to-the-north shear sense (Fig. 4d). Both top down-to-the-north and top down-to-thesouth shear bands are locally developed, however, in the Rongbuk Formation samples. Where both sets are present in a single thin section the top down-to-the-north shear bands are generally the most strongly developed. The two sets of shear bands appear to be contemporaneous, indicating a component of bulk pure shear (coaxial) deformation. The most pervasive development of single sets of shear bands (top down-to-thenorth) is in the highest-altitude samples (Fig. 4d), located at distances of $250-300 \mathrm{~m}$ beneath the Lhotse Detachment as mapped by Searle (2003). At deeper structural levels sillimanite grains are present and drawn into adjacent conjugate shear bands (Fig. $4 \mathrm{e}$ and $\mathrm{f}$ ) but still appear pristine, indicating that penetrative deformation occurred at close to peak metamorphic temperatures. Macroscopic S-C structures, consistent with a top downto-the-north shear sense, are most clearly developed in leucogranite sample ET-15. At the microscopic scale, however, both top down-to-the-north and top down-to-the-south shear bands are 

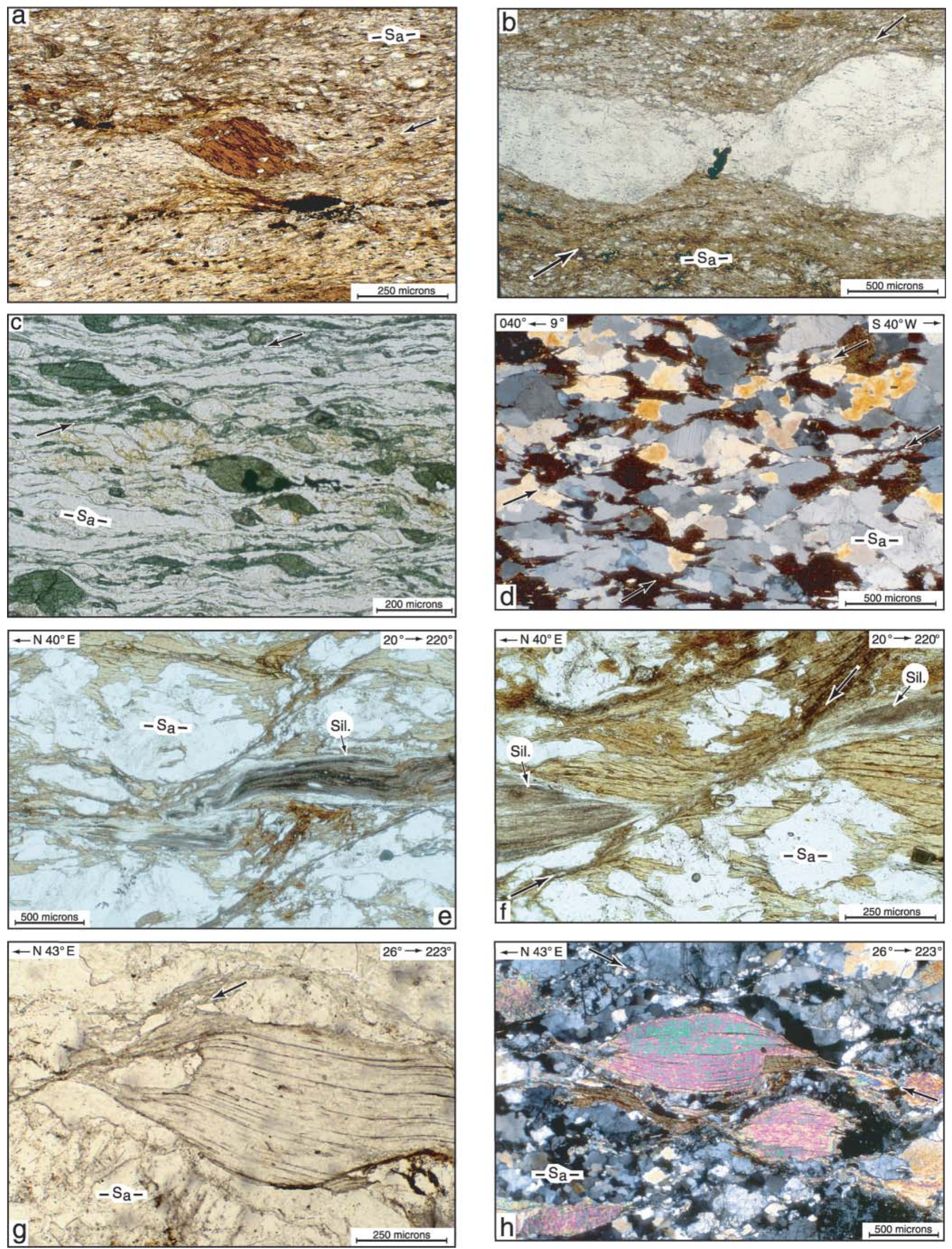


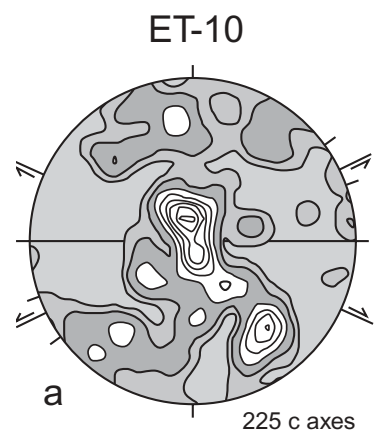

$1,2,3,4,5,6$ times uniform

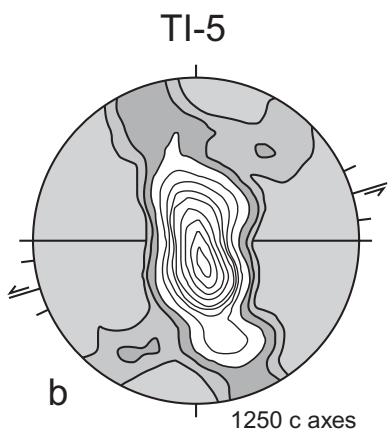

$0.25,0.5,1,2,3,4,5,7 . .13$ times uniform
Fig. 5. Optically measured quartz $c$-axis fabrics; lower hemisphere equal area projections; foliation oriented left-right and vertical, mineral lineation horizontal; range of shear band orientations and contour intervals (times uniform) indicated; sample locations are indicated in Figure 3. (a) Everest Series upper greenschist-facies (biotite-grade) pelite-psammite (sample ET-10) collected from talus pile at Advance Base Camp. (b) Rongbuk Formation mylonitic epidote amphibolite (sample TI-5) collected from talus pile at Rongbuk Monastery.

present in this sample of deformed leucogranite (Fig. $4 \mathrm{~g}$ and $\mathrm{h}$, respectively).

High deformation temperatures are also indicated by the mineral-dependent deformation mechanisms in our amphibolitefacies samples, particularly in the lower-altitude samples. For example, orthoclase and plagioclase feldspar grains are locally plastically deformed, suggesting deformation temperatures higher than $450-500{ }^{\circ} \mathrm{C}$ (Tullis \& Yund 1992; FitzGerald \& Stunitz 1993). However, in all samples the larger feldspar grains appear to have remained rigid or deformed in a brittle manner, whereas only the smaller grains exhibit undulose extinction. Traced structurally downwards the transitional feldspar grain size for brittle-plastic behaviour changes from $100-150 \mu \mathrm{m} \quad(300 \mathrm{~m}$ beneath detachment) to $350-450 \mu \mathrm{m}(650 \mathrm{~m}$ beneath detachment). All quartz microstructures in the gneiss and leucogranite samples correspond to high-temperature Regime 3 recrystallization of Hirth \& Tullis (1992). No microstructural evidence for Regime 1 or 2 recrystallization, i.e. under greenschist-facies conditions, was found in the amphibolite-facies gneisses. These 'quenched' microstructures in the amphibolite-facies rocks indicate rapid exhumation, in agreement with previous isotopic dating studies of the Rongbuk leucogranites (Hodges et al. 1998; Murphy \& Harrison 1999).

Quartz $c$-axis fabrics from our amphibolite-facies samples are shown in Figure 6; all are Type II cross-girdle fabrics as defined by Lister (1977) and contain dominant Y-axis maxima aligned within the macroscopic foliation plane at right angles to the mineral lineation. Shear bands are oriented at right angles to the crossed girdles in the quartz $c$-axis fabric diagrams (Fig. 6), indicating a genetic link between shear band and fabric development. By analogy with both experimental (e.g. Tullis 1977; Heilbronner \& Tullis 2002) and numerical simulation data (e.g. Lister \& Hobbs 1980; Jessell \& Lister 1990; Takeshita et al. 1999) these cross-girdle fabrics are interpreted to indicate approximate plane strain $(k=1)$ conditions. The sense of fabric asymmetry is in all cases consistent with a top down-to-the-north shear sense, but the degree of fabric asymmetry is not great, and is certainly less than that described from quartz-rich tectonites adjacent to the Main Central thrust at the base of the Greater Himalayan Slab in Nepal (e.g. Bouchez \& Pêcher 1976, 1981; Brunel 1986). The relatively low degree of fabric asymmetry suggests at least in a qualitative sense that there is an important component of pure shear deformation.

The Type II cross-girdle fabrics within the amphibolite-facies samples indicate deformation temperatures of $450-500{ }^{\circ} \mathrm{C}$ or higher (see reviews by Schmid \& Casey 1986; Law 1990), in agreement with minimum deformation temperatures indicated by the Regime 3 quartz recrystallization microstructures (Hirth et al. 2001; Stipp et al. 2002) and limited plastic behaviour of the feldspar grains. Below we attempt to quantify deformation temperatures using quartz $c$-axis fabric data from the Rongbuk Formation samples.

\section{Deformation temperatures}

Both experimental (e.g. Tullis et al. 1973) and numerical simulation studies (e.g. Lister \& Hobbs 1980; Lister \& Dornsiepen 1982) indicate that during plastic deformation and dynamic recrystallization the opening angle of quartz $c$-axis fabrics increases with rising deformation temperature and increasing hydrolytic weakening, and decreasing strain rate. In the case of plane strain deformation this opening angle is defined as the angle between the two $c$-axis girdles measured in the plane perpendicular to foliation and parallel to lineation. Kruhl (1998) has compiled opening angle v. temperature of metamorphism data from a range of greenschist-granulite-facies environments and demonstrated that at natural strain rates there is an approximately linear increase in opening angle with temperature between c. 300 and $650{ }^{\circ} \mathrm{C}$ (Fig. 7). At $650-800{ }^{\circ} \mathrm{C}$ there is a more rapid increase of opening angle with rising temperature, probably reflecting the low-high quartz transition and the increasing importance of prism [c] slip relative to $\langle a\rangle$ slip at the higher temperatures. Kruhl (1998, p. 143) considered that for natural deformation this opening angle thermometer may give

Fig. 4. Micrographs of samples from the Everest Series and Rongbuk Formation; all micrographs are from sections cut perpendicular to foliation and parallel to lineation. For unoriented samples $(\mathbf{a}, \mathbf{b}$ and $\mathbf{c})$, sections are viewed so that microstructures indicate a dominant sinistral shear sense. For oriented samples ( $\mathbf{d}-\mathbf{h})$ sections are viewed towards the east; as a result of local flexing of foliation, lineation locally plunges to either the NNE-NE or SSW-SW; plunge and trend of lineation in each sample are indicated. Sa, orientation of macroscopic grain-shape foliation. (See Fig. 3 for sample localities.) (a) Everest Series (sample ET-10): rhomb-shaped biotite grain (mica fish) adjacent to incipient shear bands (arrowed); plane-polarized light. (b) Everest Series (sample ET-10): extensional micro-faults (arrowed) cutting quartz vein in quartz-biotite phyllite; plane-polarized light. (c) Rongbuk Formation (sample TI-5): sheared hornblende grains in epidote amphibolite-facies mylonite sample; shear band orientation indicated by arrows; plane-polarized light. (d) Rongbuk Formation (sample ET-8): incipient top down-to-the-north shear bands (between arrows) in quartz biotite schist (note biotite enveloping quartz grains); cross-polarized light with mica plate. (e) Rongbuk Formation (sample ET-13): north-directed folding and faulting of sillimanite grain in sillimanite-biotite schist (note only minor retrogression of sillimanite (Sil.)); plane-polarized light. (f) Rongbuk Formation (sample ET-13): top down-tothe-north shear band cutting sillimanite grain (Sil.) (note only minor retrogression of sillimanite); plane-polarized light. (g) Leucogranite (sample ET-15): muscovite grain truncated by top down-to-the-north shear band (arrowed) oblique to grain shape foliation $\left(\mathrm{S}_{\mathrm{a}}\right)$; cross-polarized light. (h) Leucogranite (sample ET-15): top down-to-the-south shear bands (between arrows) oblique to muscovite grain shape foliation $\left(\mathrm{S}_{\mathrm{a}}\right)$; cross-polarized light. 


\section{Rongbuk Monastery}

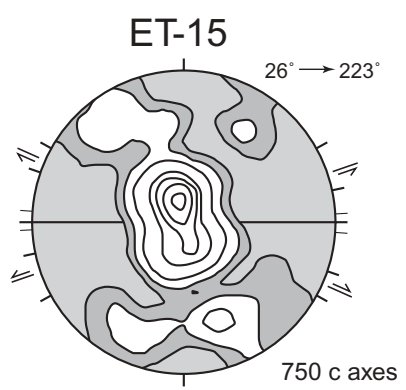

$0.5,1,2,3 . .6,7$ times uniform

ET-13

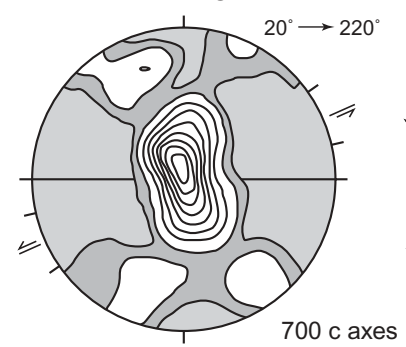

$0.5,1,2,3 . .6,7,8$ times uniform

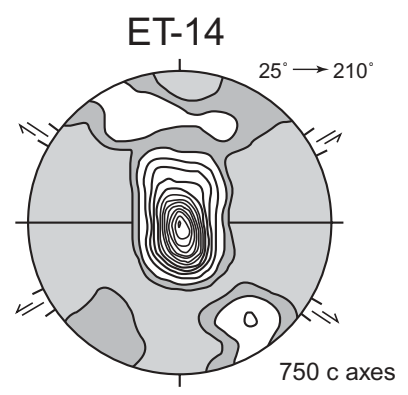

$0.5,1,2,3$.. 11, 12 times uniform

ET-12

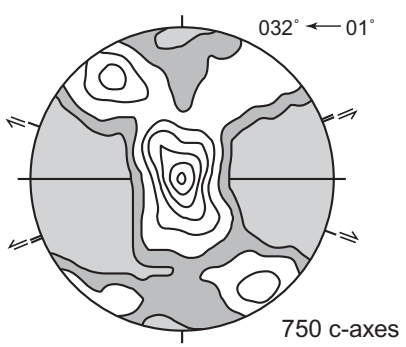

$0.5,1,2,3,4,5,6$ times uniform

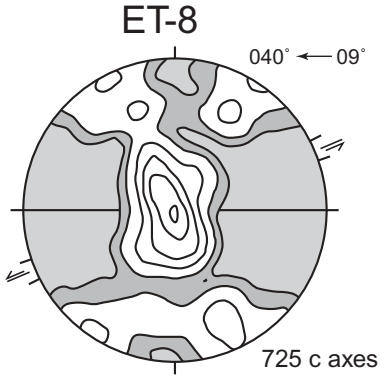

$0.5,1,2,3,4,5$ times uniform ET-6

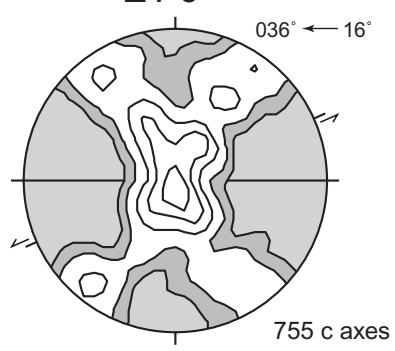

$0.5,1,2,3,4$, times uniform
ET-7

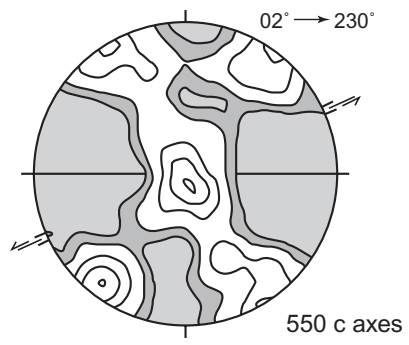

$0.5,1,2,3,4$, times uniform

\begin{abstract}
Rongbuk Monastery Traverse: samples collected at elevations of $5450 \mathrm{~m}$ (ET-15), $5350 \mathrm{~m}$ (ET-14), $5250 \mathrm{~m}$ (ET-13) and $5100 \mathrm{~m}(\mathrm{ET}-12)$.
\end{abstract}

Hermit's Gorge Traverse: samples collected at elevations of $5650 \mathrm{~m}$ (ET-8), $5600 \mathrm{~m}$ (ET-7 and 6) and $5320 \mathrm{~m}$ (ET-16).

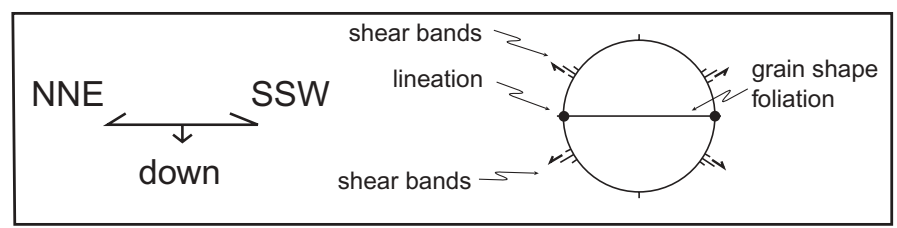

Fig. 6. Optically measured quartz $c$-axis fabrics viewed towards the east from deformed leucogranite sill (sample ET-15) and Rongbuk Formation amphibolite-facies metasedimentary rocks (remaining samples); lower hemisphere equal area projections; all in situ oriented samples; plunge and trend of lineation, range of shear band orientations and contour intervals are indicated for each sample; sample locations are indicated in Figure 3.

deformation temperatures with an uncertainty of $\pm 50{ }^{\circ} \mathrm{C}$. The underlying assumption in using this thermometer is that the degree of uncertainty spans the range of strain rates and amounts of hydrolytic weakening likely to be encountered in natural deformation. We have made minor modifications to the opening angle thermometer of Kruhl (1998) by adding data reported by Okudaira et al. (1995) and some of our own data from previous studies (Law et al. 1992; Nyman et al. 1995) (Fig. 7).

Within the Rongbuk Formation samples collected from the Rongbuk Monastery and Hermit's Gorge traverses (Fig. 3) quartz $c$-axis fabric opening angles progressively increase with distance beneath the position of the overlying Lhotse Detachment as mapped by Searle (2003). Our data indicate a linear increase in fabric opening angle with distance beneath the Lhotse Detachment, with opening angles from oriented samples collected in situ ranging from 65 to $79^{\circ}$ at projected distances of $300-670 \mathrm{~m}$ beneath the detachment (Fig. 8a). In contrast to these large opening angles, epidote amphibolite-facies sample TI-5 collected from a talus pile at the base of the Rongbuk Monastery traverse is characterized by a $57^{\circ}$ fabric opening angle. Extrapolation of the observed linear relationship between opening angle and structural depth for in situ amphibolite-facies samples suggests that sample TI-5 may have been eroded from an outcrop located at c. $150 \mathrm{~m}$ beneath the Lhotse Detachment.
Using the modified geothermometer of Kruhl (1998), fabric opening angles within the amphibolite-facies Rongbuk Formation samples indicate progressively rising deformation temperatures of $525-625 \pm 50{ }^{\circ} \mathrm{C}$ at depths of $300-650 \mathrm{~m}$ beneath the detachment (Fig. 8b). A deformation temperature of $450 \pm 50{ }^{\circ} \mathrm{C}$ is indicated by the $57^{\circ}$ fabric opening angle in epidote amphibolitefacies sample TI-5, thought to be located closer to the overlying detachment. However, the presence of rare porphyroclasts of calcic pyroxene (?augite) in sample TI-5 may indicate minimum temperatures of $500-550{ }^{\circ} \mathrm{C}$, possibly associated with an earlier phase of metamorphism.

This downward rise in deformation temperatures quantified by fabric opening angles is in good agreement with deformation temperature distribution qualitatively indicated by the systematic downward transition in quartz recrystallization regime (Regime 2 to 3), topology of quartz $c$-axis fabrics (Type I to II) and increasing plasticity of feldspar. These deformation temperatures are also in broad agreement with temperatures indicated by metamorphic mineral assemblages, although low-variance mineral assemblages suitable for quantitative thermobarometry are relatively rare in the Rongbuk Valley (Hodges et al. 1992). One pelitic Rongbuk Formation sample with an appropriate mineral assemblage for simultaneous solution of the garnet-biotite and garnet-plagioclase-sillimanite-quartz thermometers was col- 


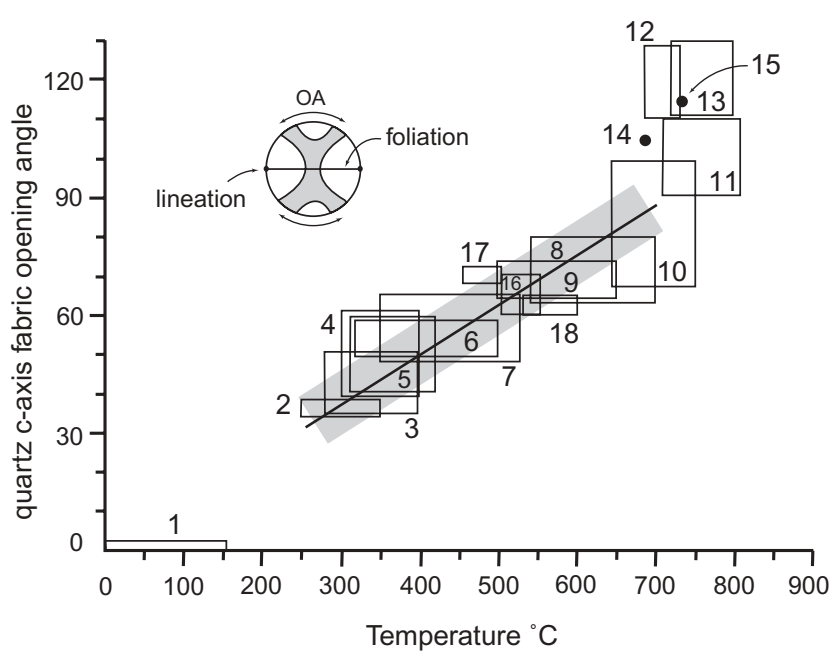

Fig. 7. Graph of quartz $c$-axis fabric opening angles v. estimated temperatures of deformation for 18 suites of naturally deformed rocks at different metamorphic grade; adapted from Kruhl (1998). Fabric opening angle (OA) defined in inset diagram. Boxes 1-15 indicate data taken from the literature or slightly modified by Kruhl (1998); boxes 16-18 indicate data from Law et al. (1992), Nyman et al. (1995) and Okudaira et al. (1995), respectively. Best-fit straight-line relationship between opening angle and temperature is indicated for localities with deformation temperatures $<650{ }^{\circ} \mathrm{C}$; grey bar indicates $\pm 50{ }^{\circ} \mathrm{C}$ confidence limit; higher deformation temperatures inferred to promote prism $[c]$ slip and different relationship between deformation temperature and opening angle.

lected by Hodges et al. (1992; their sample R74) from the junction between Hermit's Gorge and the Rongbuk Valley at the same locality as our sample ET-16 (Fig. 3). The quartz $c$-axis fabric opening angle in sample ET-16 indicates a deformation temperature of $625 \pm 50{ }^{\circ} \mathrm{C}$ (Fig. 8b), in good agreement with calculated final equilibration conditions of $630{ }^{\circ} \mathrm{C}$ and $4.6 \mathrm{kbar}$ for sample R74 (Hodges et al. 1992).

Clearly, the fabric opening angle in leucogranite sample ET15 , collected in situ at an estimated distance of $250 \mathrm{~m}$ beneath the Lhotse Detachment (Fig. 8), does not agree with the linear relationship between opening angle-deformation temperature and structural position shown by the surrounding Rongbuk Formation samples. We speculate that the higher fabric opening angle in the leucogranite, relative to the surrounding metasedimentary rocks, may indicate that plastic deformation of the leucogranite occurred before the intrusion cooled to ambient temperature. This, in turn, may indicate that intrusion occurred at a late stage during top down-to-the-north penetrative deformation.

\section{Vorticity and strain analyses}

Three techniques for quantifying vorticity of flow have proved applicable to our samples: Method 1, the porphyroclast distribution method of Wallis et al. (1993); Method 2, the porphyroclast hyperbolic distribution method of Simpson \& De Paor (1997); Method 3, the quartz $c$-axis fabric and strain ratio method of Wallis $(1992,1995)$. All three methods employ data collected on section planes cut perpendicular to foliation and parallel to lineation. The methods assume that the vorticity vector is oriented perpendicular to the maximum and minimum principal axes of finite strain (i.e. lies along the intermediate principal stretching rate axis during progressive flow), and that a noncoaxial flow will lead to formation of fabrics with monoclinic symmetry (S. Wallis, pers. comm.). However, although the three methods do assume a minimum of monoclinic symmetry, they remain valid for general $3 \mathrm{D}$ strains and do not assume plane strain $(\mathrm{k}=1)$ deformation conditions (D. De Paor, pers. comm.; S. Wallis, pers. comm.). As discussed above, approximate plane
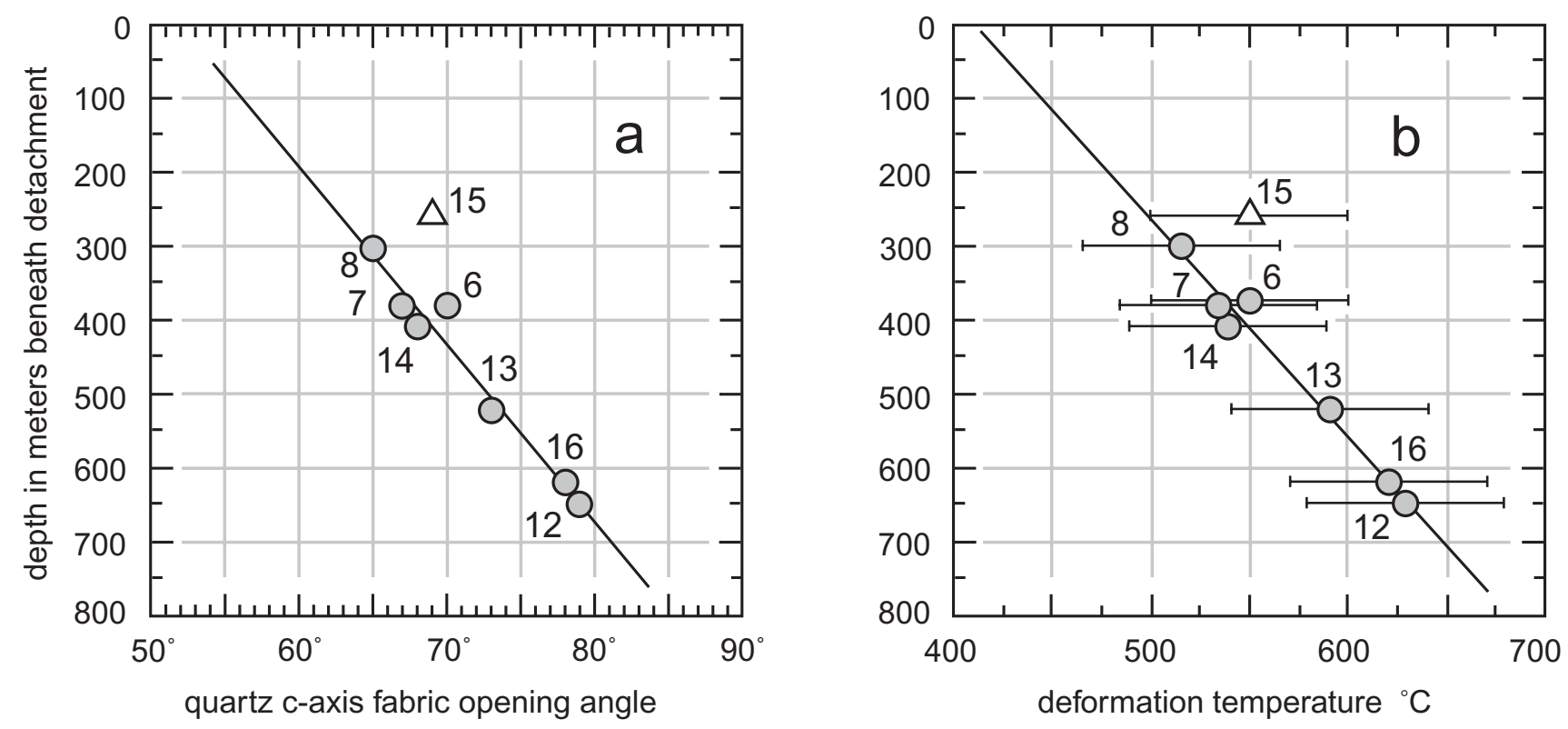

Fig. 8. (a) Quartz c-axis fabric opening angles v. estimated distance beneath Lhotse Detachment as mapped by Searle (2003); sample ET-15 is deformed leucogranite, all other samples are Rongbuk Formation amphibolite-facies metasedimentary rocks; linear regression line for metasedimentary rocks is indicated. (b) Deformation temperatures indicated by the modified geothermometer of Kruhl (1998) v. estimated distance beneath Lhotse Detachment; $\pm 50{ }^{\circ} \mathrm{C}$ error bars are shown; linear regression line for metasedimentary rocks indicates an apparent vertical gradient in deformation temperatures of $330{ }^{\circ} \mathrm{C} \mathrm{km}{ }^{-1}$. 
strain deformation conditions are indicated by the cross-girdle pattern of quartz $c$-axis fabrics in our samples, and the orthogonal relationship between the cross-girdle fabric and sample $Y$ direction (within foliation and perpendicular to lineation) also argues for monoclinic rather than triclinic flow (Lin et al. 1998; Passchier 1998).

For plane strain deformation, components of pure shear and simple shear can be quantified in terms of the kinematic vorticity number $W_{\mathrm{k}}$ (Means et al. 1980). Care must be taken, however, in interpreting estimated vorticity numbers $\left(W_{\mathrm{k}}\right)$ in terms of the relative contributions of pure and simple shear deformation. This is because $W_{\mathrm{k}}$ is defined (for $0 \leqslant W_{\mathrm{k}} \leqslant 1$ ) as the non-linear ratio of pure shear $\left(W_{\mathrm{k}}=0\right)$ and simple shear $\left(W_{\mathrm{k}}=1\right)$ components of deformation, assuming a steady-state deformation (Means 1994). Pure and simple shear components make equal contributions to the instantaneous flow at $W_{\mathrm{k}}=0.71$ (Fig. 9).

In natural systems the vorticity of flow may vary with both position and time (Fossen \& Tikoff 1998; Jiang 1998 and references therein). In such cases of non-steady-state deformation, flow is more appropriately characterized by the mean kinematic vorticity number $W_{\mathrm{m}}$ in which the vorticity of flow is integrated over space and time (Passchier 1988). For steady-state deformation $W_{\mathrm{k}}$ (instantaneous deformation) is equal to $W_{\mathrm{m}}$ (finite deformation). The likelihood of non-steady-state flow in natural deformation presents a fundamental problem for meaningful vorticity analysis using microstructures and finite strain features. For example, do these analytical techniques provide a time-averaged measure of flow, or do at least some techniques (e.g. those using microstructures such as recrystallized grains with short 'strain memories') provide only a measure of the last few increments of flow? In our vorticity analysis of the Everest samples we have attempted to at least partially address this problem by applying as many vorticity analysis methods as

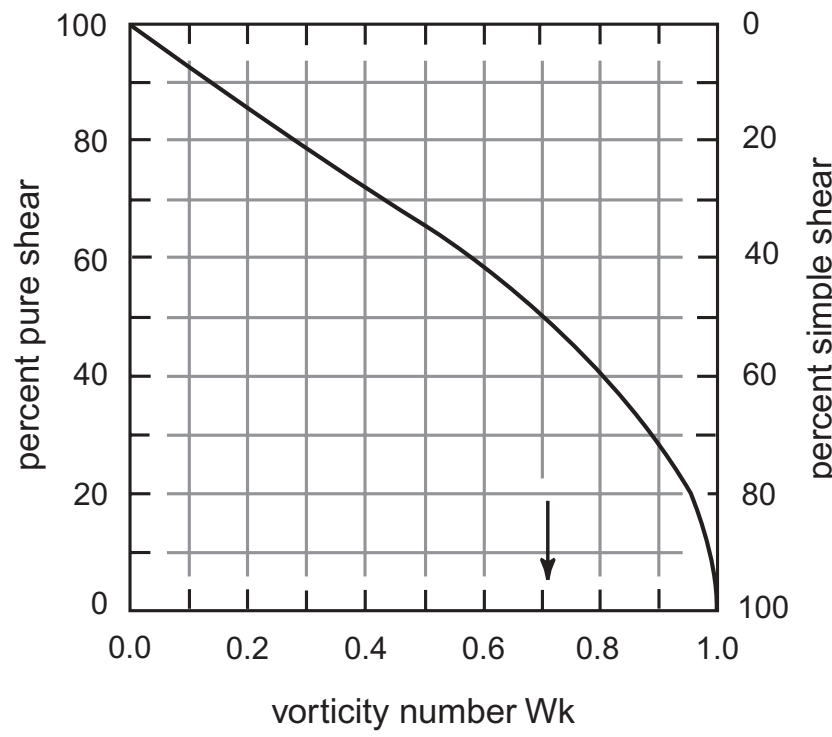

Fig. 9. Relationship between kinematic vorticity number $W_{\mathrm{k}}$ and components of pure and simple shear for instantaneous 2D flow; pure and simple shear components make equal contributions to flow at $W_{\mathrm{k}}=0.71$ (arrow). $W_{\mathrm{k}}=\cos \alpha$, where $\alpha$ is the angle between flow apophyses (Bobyarchick 1986), and varies from $0^{\circ}$ (simple shear) to $90^{\circ}$ (pure shear). Relative proportion of pure shear to simple shear is given by $\alpha / 90^{\circ}$; at $\alpha=45^{\circ}$ there should be an equal contribution of pure and simple shear $\left(45^{\circ} / 90^{\circ}=0.5\right)$; for simple shear there is no pure shear component $\left(0^{\circ} / 90^{\circ}=0\right)$. Method suggested by B. Tikoff (pers. comm.). possible in a given sample, thereby allowing us to evaluate the reliability and consistency of vorticity data indicated by the various methods (see Xypolias \& Koukouvelas 2001 for a similar approach). Results of our analyses are expressed in terms of mean kinematic vorticity number $W_{\mathrm{m}}$. For each method of vorticity analysis applied to a given sample, a range of vorticity numbers is given, where this range reflects the degree of uncertainty in the input parameters used to estimate $W_{\mathrm{m}}$.

\section{Method 1}

This method is based on measuring the orientation and aspect ratio of rigid porphyroclasts rotating in a homogeneously deforming matrix, and finding a critical aspect ratio $\left(R_{\mathrm{c}}\right)$ below which porphyroclasts continuously rotate and hence their long axes display no finite preferred alignment, and above which they achieve stable end orientations. This method was proposed by Wallis et al. (1993) and assumes no mechanical interaction between porphyroclasts (see also Passchier 1987; Tikoff \& Teyssier 1994). For the Rongbuk Formation samples this method has been applied only to porphyroclasts (mainly feldspar, but also amphibole, epidote, tourmaline and zircon grains) lacking evidence for plastic deformation (Fig. 10).

For Method 1 the range of $W_{\mathrm{m}}$ values estimated for each sample reflects the degree of uncertainty in determining $R_{\mathrm{c}}$ (Figs 10 and 11). $W_{\mathrm{m}}$ values estimated by Method 1 range from 0.67 to 0.85 (Fig. 11). This method may tend to underestimate the vorticity number if clasts of large aspect ratio are not present, and therefore within individual samples the upper bound of this $W_{\mathrm{m}}$ range is probably closest to the true value, as indicated by the close correlation between $W_{\mathrm{m}}$ estimates from Methods 1 and 2 in sample TI-5 (Figs 10-12). The upper limit of $W_{\mathrm{m}}$ for individual samples estimated by Method 1 ranges between 0.73 and 0.85 .

\section{Method 2}

This method was proposed by Simpson \& De Paor (1993, 1997) and is based on recording on a hyperbolic net the orientation and aspect ratio of porphyroclasts that have either forward rotated or back rotated within a homogeneous deforming matrix, and coding these data with respect to the type of recrystallization tail (sigma and delta) that develops on individual clasts. The hyperbola that encloses all back-rotated sigma-type porphyroclasts, and separates them from all other types, is chosen. One limb of this hyperbola is asymptotic to the foliation, and the mean kinematic vorticity number $W_{\mathrm{m}}$ is given by the cosine of the acute angle between the two limbs of the hyperbola. At the thin-section scale Method 2 was appropriate only for sample TI5.

A $W_{\mathrm{m}}$ value of 0.79 is estimated for sample TI-5 using Method 2 (Fig. 12), and this result is in good agreement with the $W_{\mathrm{m}}$ value $(0.77-0.79)$ indicated by Method 1 for the same sample (Fig. 11). In our Method 2 analysis the most acute hyperbola available on the hyperbolic net was used to enclose the backrotated sigma-type porphyroclasts, thus reducing the pure shear component to a minimum (Simpson \& De Paor 1997, p. 175). The estimated $W_{\mathrm{m}}$ value using Method 2 is therefore regarded as a maximum value.

\section{Method 3}

This method is based on measuring quartz $c$-axis fabrics and strain ratio in the $X Z$-plane of finite strain $(R x z)$; details of the 

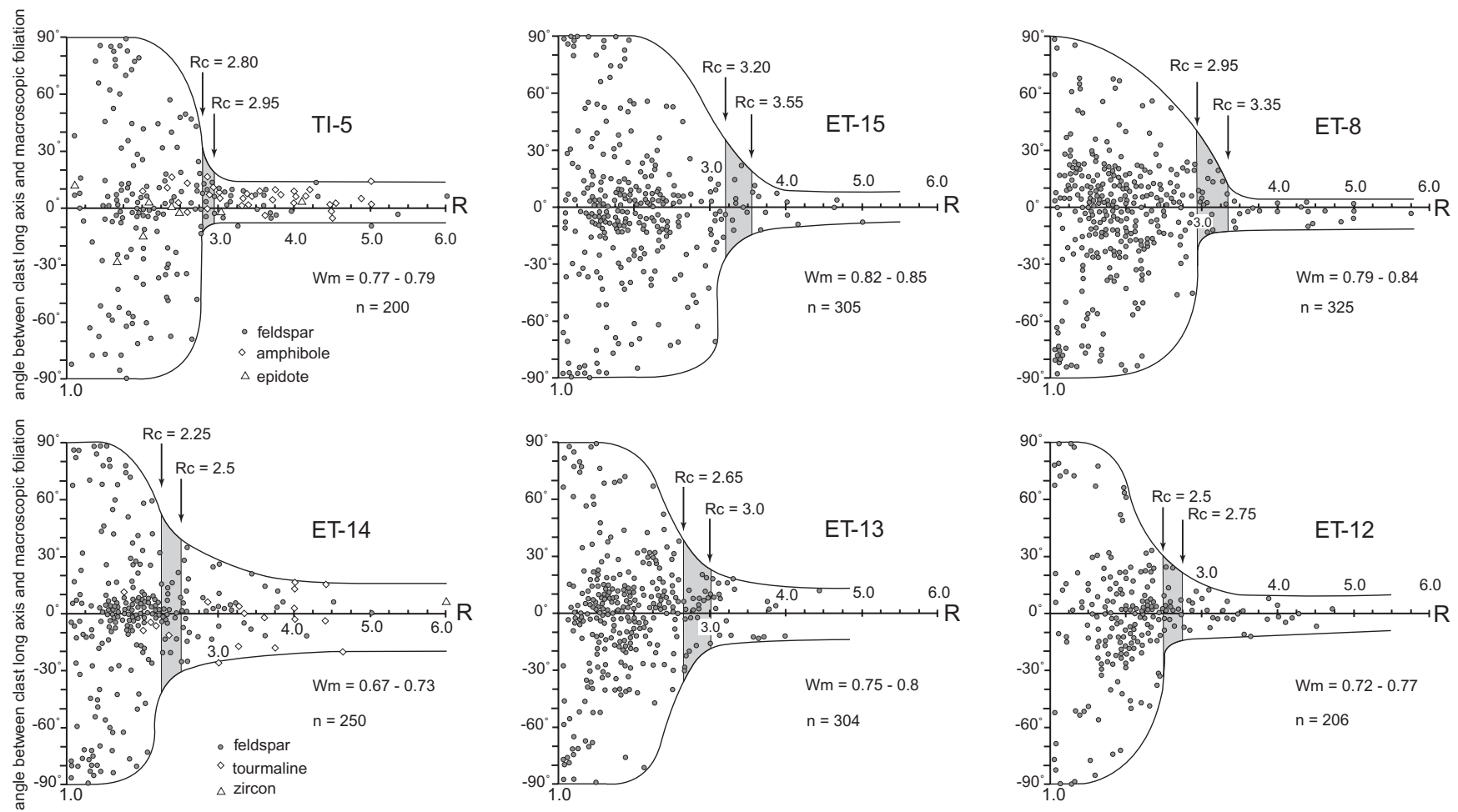

Fig. 10. Orientation analysis (Method 1) for feldspar porphyroclasts, plus hornblende and epidote (sample TI-5), and tourmaline and zircon (sample ET14). Data from sections cut perpendicular to foliation and parallel to lineation; $n$ is number of grains measured in each section. $R$ is aspect ratio of porphyroclasts: a positive angle between clast long axes and foliation indicates that clast long axis is inclined towards top-to-the-north shear sense; a negative angle indicates that clast long axis is inclined against shear sense. $R_{\mathrm{c}}$ is critical aspect ratio below which clasts are inferred to continuously rotate and above which they attain a stable orientation; range of uncertainty in $R_{\mathrm{c}}$ value is indicated for each sample. $R_{\mathrm{c}}$ is a function of mean kinematic vorticity number $\left(W_{\mathrm{m}}\right)$, where $W_{\mathrm{m}}=\left(R_{\mathrm{c}}^{2}-1\right) /\left(R_{\mathrm{c}}^{2}+1\right)$ (Passchier 1987; Wallis et al. 1993). $W_{\mathrm{m}}$ estimates for each sample reflect the range of uncertainty in $R_{\mathrm{c}}$ values.

analytical procedure are summarized in Figure 13. The method was proposed by Wallis $(1992,1995)$ and has recently been applied to the base of the Greater Himalayan Slab in NW India (Grasemann et al. 1999). Although the original method of Wallis (1992, 1995) used Type I cross-girdle $c$-axis fabrics, numerical simulations by Lister \& Hobbs (1980, their model C) and Jessell \& Lister (1990) indicate that Type II cross-girdles should also be applicable to this method. In samples from the Everest Series and Rongbuk Formation quartz grain shape have been used for strain analysis, but only in those samples in which original quartz grain shape aspect ratios and orientations have been preserved by biotite grains inhibiting quartz grain boundary migration (Fig. 4d). A minimum of 100 grains were measured in each sample. Using the program MACSTRAIN 2.4 (Kanagawa 1992) each grain shape dataset was analysed using both the matrix method of Shimamoto \& Ikeda (1976) and the $R_{\mathrm{f}} /$ phi/theta curve method of Lisle (1985). Calculated strain ratios in $X Z$ sections ranged between 2.25 and 3.55 (Table 1).

$W_{\mathrm{m}}$ values estimated by Method 3 range from 0.78 to 0.98 (Fig. 11). For Method 3 the range of $W_{\mathrm{m}}$ values estimated for each sample reflects both the degree of uncertainty in measuring the angle between foliation and the normal to the leading edge of the $c$-axis fabric (Fig. 13), and differences in 2D strain estimates indicated by the matrix and $R_{\mathrm{f}} /$ phi/theta curve methods (Table 1 ). Grasemann et al. (1999, fig. 10b) have demonstrated that Method 3 vorticity analyses are unreliable in high-strain samples $\left(R_{x z}\right.$ $>10-15$ ) located near the base of the Greater Himalayan Slab because the central segment of the $c$-axis cross-girdle should theoretically be at a similar inclination to foliation for a wide range of vorticity numbers. This restriction on use of Method 3 analyses does not apply to our relatively low-strain samples $\left(R_{x z}=2.25-3.55\right)$ collected near the top of the Greater Himalayan Slab.

\section{Comparison of vorticity estimates}

Estimated $W_{\mathrm{m}}$ values for our samples range between 0.67 and 0.98 , depending on structural position, analytical method used and uncertainties in each analysis (Fig. 11). Within individual samples, $W_{\mathrm{m}}$ values estimated by Method 3 are consistently higher than values estimated by Method 1. This difference could be due to a number of causes including: (1) analytical problems associated with individual methods (e.g. Method 1 tending to give a minimum estimate of $W_{\mathrm{m}}$ if rigid grains of sufficiently high aspect ratio are not present); (2) the two methods recording different parts of the deformation history (i.e. they have different lengths of 'strain memory'); (3) the two methods reflecting a contrast in synchronous flow behaviour between rigid particle rotation of the porphyroclasts and plastic deformation of the surrounding matrix quartz grains. At present we are unable to discriminate between these possibilities. It is clear, however, that both methods indicate significant components of pure shear relative to simple shear deformation (Fig. 11). Taking into account uncertainties in our estimates of $W_{\mathrm{m}}$, Method 1 analyses indicate pure shear components representing $53-35 \%$ of the total recorded deformation (corresponding to $W_{\mathrm{m}}$ values ranging from 


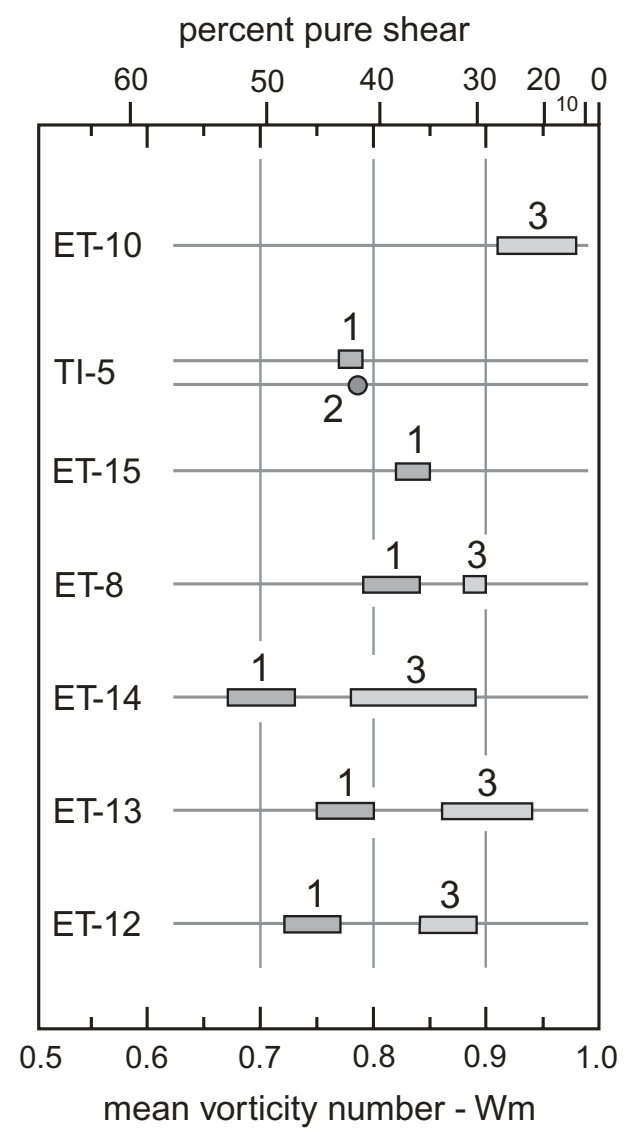

Fig. 11. Bar chart for range of mean kinematic vorticity numbers $W_{\mathrm{m}}$ estimated by Methods 1 and 3 for samples from the Everest Series (ET10), deformed leucogranite sill (ET-15), Rongbuk Formation epidote amphibolite (TI-5) and amphibolite-facies metasedimentary rocks (remaining samples). Length of bars reflects degree of uncertainty in the input parameters used to estimate $W_{\mathrm{m}}$. For sample T-5, $W_{\mathrm{m}}$ value estimated by Method 2 is indicated by circle. Relationship between pure shear contribution and vorticity number $W_{\mathrm{m}}$ is indicated (see Fig. 9).
0.67 to 0.85 ). Method 3 analyses indicate pure shear components of $43-13 \%$ ( $W_{\mathrm{m}}$ values ranging from 0.78 to 0.98 ).

\section{Strain and vorticity of flow}

Our vorticity analyses indicate significant components of pure shear (i.e. plane strain coaxial deformation) associated with north-directed shearing along the top of the Greater Himalayan Slab. Simple shear deformation is generally dominant at the highest structural levels, particularly in greenschist-facies mylonites above the Lhotse Detachment (Everest Series sample ET10) where the pure shear component is estimated at only 13$27 \%$ (Fig. 11). However, there are major components of pure shear deformation (estimated at 25-53\%) in epidote amphibolite- and amphibolite-facies Rongbuk Formation samples located at $400-650 \mathrm{~m}$ beneath the detachment (Fig. 11).

Assuming that the upper surface of the Greater Himalayan Slab marks a shear-zone boundary (i.e. flow plane) then calculation of the principal stretch magnitudes both perpendicular and parallel to this plane may be made taking into account both strain magnitude and vorticity of flow. An analytical solution to this problem has been given by Wallis et al. (1993) and is used here (Fig. 14). Shortening values of $10-30 \%$ measured perpendicular to the flow plane are calculated using strain-vorticity data from individual samples, and taking into account uncertainties in $\mathrm{W}_{\mathrm{m}}$ values indicated by the three vorticity methods (Fig. 15a). Assuming plane strain deformation, these data correspond to estimated stretches of $10-40 \%$ measured parallel to the flow plane-transport direction (Fig. 15b).

\section{Tectonic implications}

Although our data were admittedly collected only from near the upper surface of the Greater Himalayan Slab, in combination with similar estimates for vorticity of flow along the base of the slab (Grasemann et al. 1999), they indicate that pure shear (coaxial) components of deformation may have played a significant role in extrusion and exhumation of the slab. Identification of a pure shear component within the Greater Himalayan Slab is

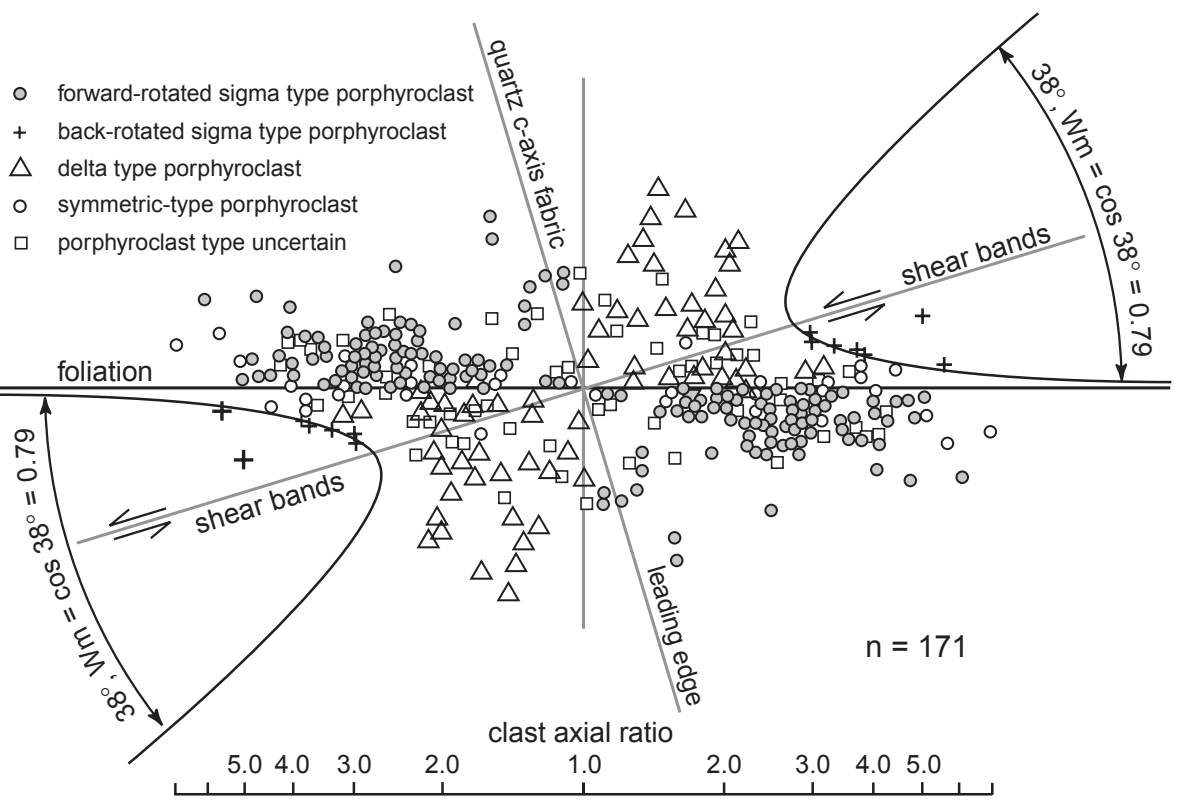

Fig. 12. Porphyroclast hyperbolic distribution polar plot (Method 2) for Rongbuk Formation epidote amphibolite sample TI-5. Estimated orientation of flow apophyses is given by the hyperbola that encloses all back-rotated sigma-type porphyroclasts, and separates them from all other types. One limb of this hyperbola is asymptotic to the foliation, and the mean kinematic vorticity number $W_{\mathrm{m}}$ is given by the cosine of the acute angle between the two limbs of the hyperbola. Average orientation of shear bands in this sample (Figs $4 \mathrm{c}$ and $5 \mathrm{~b}$ ) approximately bisects acute angle between flow apophyses (limbs of hyperbola), and central segment of leading edge of quartz $c$-axis fabric is orthogonal to average shear band orientation (Figs $5 \mathrm{~b}$ and 13 ). 


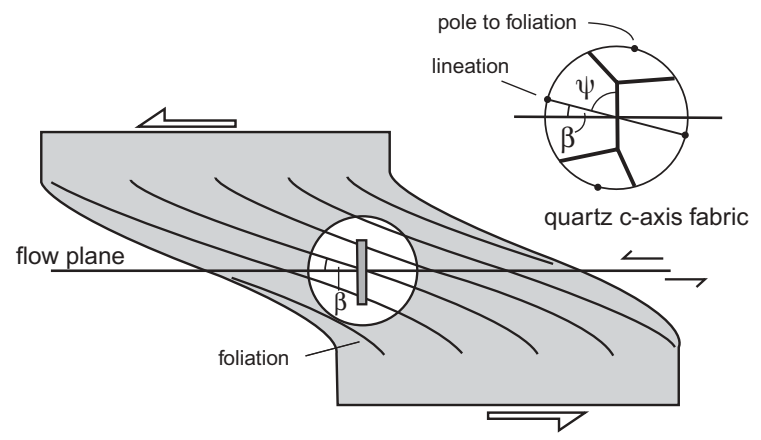

$W_{m}=\sin \left\{\tan ^{-1}\left[\frac{\sin (2 \beta)}{\left[\left(R_{X Z}+1\right) /\left(R_{X Z}-1\right)\right]-\cos (2 \beta)}\right]\right\} \times \frac{\left(R_{X Z}+1\right)}{\left(R_{X Z}-1\right)}$

$\mathrm{W}_{\mathrm{m}}=$ mean kinematic vorticity number $\quad \mathrm{R}_{X Z}=$ strain ratio in $X Z$ section

Fig. 13. Explanation of Method 3 vorticity analysis (after Wallis 1995). Flow plane is inferred to be orthogonal to central segment of the leading edge of quartz $c$-axis fabric, measured in section oriented perpendicular to foliation and parallel to lineation. Acute angle between foliation and inferred flow plane (i.e. normal to central segment of fabric) defines $\beta$; complementary angle $\psi$ between foliation and central segment of fabric is a measure of external fabric asymmetry (see review by Law 1990). In Method 3 analyses $\beta$ is used in combination with the ratio of principal stretches, $R_{x z}=\left(1+e_{1}\right) /\left(1+e_{3}\right)$, to estimate mean kinematic vorticity number $W_{\mathrm{m}}$.

critically important, because a general non-coaxial flow with a significant component of pure shear would result in the following features: (1) thinning and resultant dip-parallel extension of the slab itself; the slab could, however, maintain or even increase its thickness if additional material was continuously accreted onto its base during underthrusting; (2) relative to simple shear, an increase in both local strain rates (Pfiffner \& Ramsay 1982) and extrusion-exhumation rates (Thompson et al. 1997; Hodges et al. 2001), with tectonic movement accelerating towards the topographical surface (Vannay \& Grasemann 2001); (3) in the centre of the slab, both the extruding to shallower structural levels of higher-grade metamorphic rocks than that produced by simple shear alone, and an increase in the spacing between isograds; (4) at the margins of the slab, a markedly greater decrease in isograd spacing than that produced by simple shear alone (Grujic et al. 1996; Grasemann et al. 1999; Stephenson et al. 2001). Our integrated strain and vorticity data indicate a shortening of $10-30 \%$ perpendicular to the upper surface of the Greater Himalayan Slab and confirm that the upper surface of

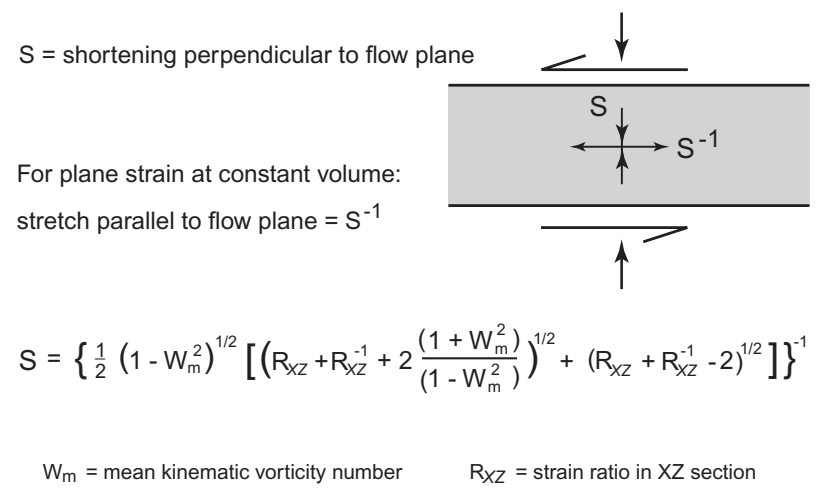

Fig. 14. Calculation of shortening value $(S)$ measured perpendicular to flow plane, taking into account both strain magnitude and vorticity of flow (adapted from Wallis et al. 1993). Assuming plane strain deformation, stretch measured parallel to the flow plane in the transport direction is given by $S^{-1}$. (See Fig. 13 for explanation of other parameters.)

the slab is a 'stretching fault' in the sense of Means (1989) with estimated down-dip stretches of 10-40\% (assuming plane strain deformation) measured parallel to the flow plane-transport direction.

A minimum age of $c .17 \mathrm{Ma}$ for ductile top down-to-the-north deformation at the top of the Greater Himalayan Slab is indicated by the $\mathrm{U}-\mathrm{Pb}, \mathrm{Th}-\mathrm{Pb}$ and ${ }^{40} \mathrm{Ar} /{ }^{39} \mathrm{Ar}$ data from mylonitic leucogranites that cut the Rongbuk Formation rocks (see above). However, quartz $c$-axis fabric data from Rongbuk Formation samples collected at more than $350-450 \mathrm{~m}$ beneath the Lhotse Detachment (Fig. 8), as mapped by Searle (2003), may indicate that penetrative top down-to-the-north deformation had commenced by at least $20 \mathrm{Ma}$. The close agreement between deformation temperature of $625 \pm 50{ }^{\circ} \mathrm{C}$ indicated by quartz $c$ axis fabric opening angle in sample ET-16 (Fig. 8b) and a final equilibration conditions of $630^{\circ} \mathrm{C}$ and $4.6 \mathrm{kbar}$ for sample R74 (Hodges et al. 1992), both collected at the junction between Hermit's Gorge and Rongbuk Valley (Fig. 3), has been noted above. Conjugate shear bands in sample ET-16 indicate a significant component of pure shear deformation, but asymmetry in the $c$-axis fabric also indicates a component of top down-to-the-north shearing (Fig. 6). This high-temperature shearing in ET-16 would seem to push back the initiation age for normal-sense shearing to before $16-18 \mathrm{Ma}$ because c. $20 \mathrm{Ma}{ }^{40} \mathrm{Ar} /{ }^{39} \mathrm{Ar}$ amphibole and U$\mathrm{Pb}$ titanite ages obtained by Hodges et al. (1992), from samples collected near the junction between Hermit's Gorge and Rongbuk Valley, pertain to cooling below c. $500{ }^{\circ} \mathrm{C}$. Even with rapid

Table 1. Petrofabric, strain and vorticity analysis data for samples from the Everest (ET-10) and Rongbuk formations

\begin{tabular}{|c|c|c|c|c|c|c|c|c|c|c|c|}
\hline Sample & Altitude (m) & Metamorphic grade & $\begin{array}{l}\text { Qtz fabric opening } \\
\text { angle (deg) }\end{array}$ & $\begin{array}{c}T\left({ }^{\circ} \mathrm{C}\right) \text { from } \\
\text { opening angle } \\
\text { (deg) }\end{array}$ & $\begin{array}{l}\text { Qtz fabric } \beta \text { angle } \\
\text { (deg) }\end{array}$ & $\begin{array}{c}R_{\mathrm{xz}}{ }^{1} \\
\left(R_{\mathrm{f}} / \mathrm{phi} /\right. \\
\text { theta) }\end{array}$ & $R_{\mathrm{xz}}^{2}(\mathrm{~S} \& \mathrm{I})$ & $R_{\mathrm{c}}$ (feldspar) & $W_{\mathrm{m}}$, Method 1 & $W_{\mathrm{m}}$, Method 2 & $W_{\mathrm{m}}$, Method 3 \\
\hline ET-10 & $>7000$ & Greenschist-biotite & - & - & $20-26$ & 2.75 & 2.84 & - & - & - & $0.91-0.98$ \\
\hline TI-5 & ?c. 5800 & Epidote amphibolite & 57 & $460 \pm 50$ & $15-17$ & - & - & $2.80-2.95$ & $0.77-0.79$ & 0.79 & - \\
\hline ET-15 & 5450 & Leucogranite & 69 & $550 \pm 50$ & 17 & - & - & $3.20-3.55$ & $0.82-0.85$ & - & - \\
\hline ET-14 & 5350 & Amphibolite & 68 & $540 \pm 50$ & $16-19$ & 2.56 & 2.84 & $2.25-2.50$ & $0.67-0.73$ & - & $0.78-0.89$ \\
\hline ET-13 & 5250 & Amphibolite-sillimanite & 73 & $590 \pm 50$ & $18-22$ & 2.75 & 2.84 & $2.65-3.00$ & $0.75-0.80$ & - & $0.86-0.94$ \\
\hline ET-12 & 5100 & Amphibolite & 79 & $630 \pm 50$ & $18-20$ & 2.5 & 2.55 & $2.50-2.70$ & $0.72-0.77$ & - & $0.84-0.89$ \\
\hline ET-08 & 5650 & Lower amphibolite & 65 & $515 \pm 50$ & $22-23$ & 2.05 & 2.1 & $2.95-3.35$ & $0.79-0.84$ & - & $0.88-0.90$ \\
\hline ET-07 & 5600 & Amphibolite & 67 & $535 \pm 50$ & 23 & - & - & - & - & - & - \\
\hline ET-06 & 5600 & Amphibolite & 70 & $550 \pm 50$ & $23-25$ & - & - & - & - & - & - \\
\hline ET-16 & 5320 & Amphibolite & 78 & $625 \pm 50$ & 30 & - & - & - & - & - & - \\
\hline
\end{tabular}

${ }^{1}$ Strain ratio estimated from deformed quartz grains in $X Z$ section plane using $R_{\mathrm{f}} /$ phi/theta method of Lisle (1985).

${ }^{2}$ Strain ratio estimated from deformed quartz grains in $X Z$ section plane using matrix method of Shimamota \& Ikeda (1976). 


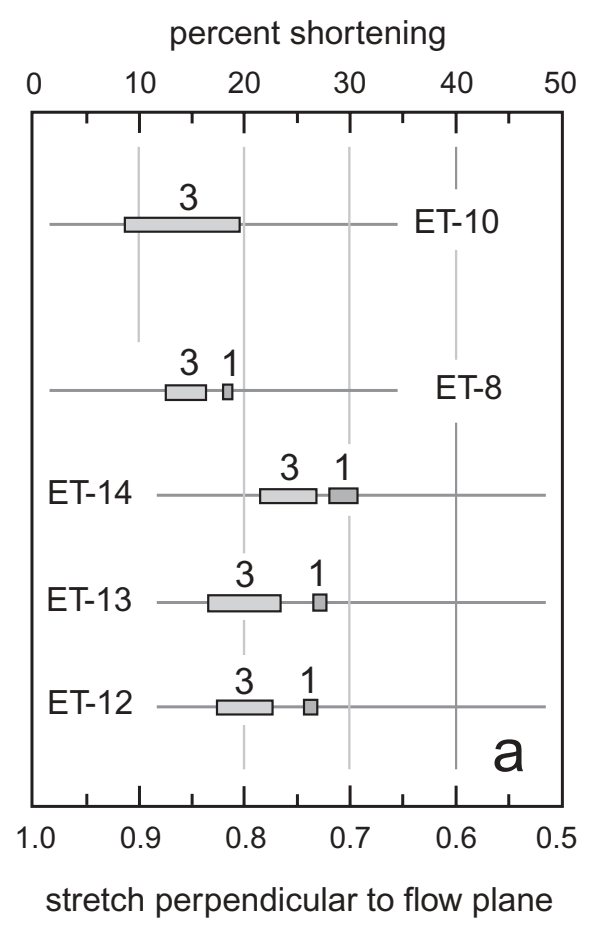

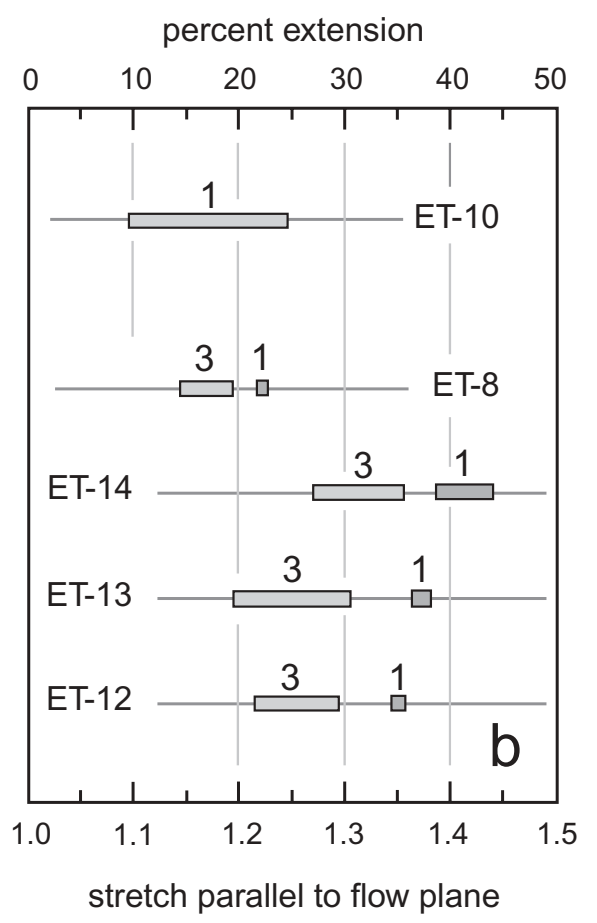

Fig. 15. (a) Bar chart for range of shortening values measured perpendicular to flow plane (i.e. upper surface of Greater Himalayan Slab), taking into account both strain magnitude and vorticity of flow estimated by Methods 1 and 3, for individual samples from the Everest Series (sample ET-10) and Rongbuk Formation amphibolite-facies metasedimentary rocks (remaining samples). Length of bars reflects differences in the ratio of principal stretches, $R_{x z}=\left(1+e_{1}\right) /\left(1+e_{3}\right)$, estimated by the matrix and $R_{\mathrm{f}} /$ phi/theta curve methods (Table 1) and uncertainties in the input parameters used to estimate $W_{\mathrm{m}}$. (b) Corresponding bar chart for estimated stretches parallel to flow plane in the transport direction, assuming plane strain deformation. cooling after peak metamorphism, top down-to-the-north shearing at $625^{\circ} \mathrm{C}$ would have to be pre-20 Ma (K. Hodges, pers. comm.).

Some doubt is cast on this interpretation, however, by more recent isotopic studies by Searle et al. (2003; their sample E282) of a Qtz $+\mathrm{Pl}+\mathrm{Mc}+\mathrm{Bt}$ schist also collected at the junction between Hermit's Gorge and Rongbuk Valley. Three multi-grain fractions of monazite from sample E282 were analysed by both $\mathrm{U}-\mathrm{Th}$ and $\mathrm{Th}-\mathrm{Pb}$ methods. Two fractions (M-1 and $\mathrm{M}-3$ ) plot concordantly at $16.9 \pm 0.1 \mathrm{Ma}$ and have similar ${ }^{208} \mathrm{~Pb} /{ }^{232} \mathrm{Th}$ ages $(16.6-16.9 \mathrm{Ma})$, whereas the third fraction (M-3) is normally discordant in the $\mathrm{U}-\mathrm{Pb}$ system with a ${ }^{208} \mathrm{~Pb} /{ }^{232} \mathrm{Th}$ age of $18.3 \pm 0.2 \mathrm{Ma}$. Searle et al. (2003) interpreted the weighted mean age of $16.9 \pm 0.2 \mathrm{Ma}$ for fractions $\mathrm{M}-1$ and $\mathrm{M}-3$ as indicating the crystallization age of metamorphic monazite in sample E282, whereas the older age in fraction M-2 is thought to indicate monazite inheritance. As pointed out by Searle et al. (2003, p. 360) the inferred monazite crystallization age of $16.9 \pm 0.2 \mathrm{Ma}$ for sample E282 is not compatible with the $c$. $20 \mathrm{Ma}$ age for amphibolite-facies metamorphism obtained at the same structural position by Hodges et al. (1992) unless this metamorphic event was protracted.

Our microstructural and quartz-fabric data are consistent with a rapid decrease in $P-T$ conditions and indicate an anomalously high apparent vertical gradient in deformation temperatures near the top of the Greater Himalayan Slab (Fig. 8b). The measured strains in our samples (Table 1) are too low for this extreme apparent gradient $\left(\right.$ c. $\left.330{ }^{\circ} \mathrm{C} \mathrm{km}^{-1}\right)$ to be solely explained by strain-induced telescoping of isotherms. At present we are unable to determine if our samples all reached peak deformation temperatures at the same time, or if the anomalously high apparent gradient could be explained by samples following different material paths during extrusion-exhumation. Geometric and numerical modelling studies of rapid exhumation-related cooling histories (e.g. Grasemann \& Mancktelow 1993) indicate that such petrological data could significantly overestimate geothermal gradients prevailing during normal-sense motion along the top of the Greater Himalayan Slab. Alternatively, the inferred rapid upward fall in deformation temperatures towards the overlying Lhotse Detachment could indicate chilling of the plastically deforming mid-crustal rocks in the uppermost part of the slab against overlying cooler upper-crustal rocks during rapid southward-directed extrusion of the slab. The degree of chilling would presumably be a function of both the rate of normal-sense motion on the detachment system and the thermal conductivity of the rocks involved.

Our vorticity data from the top of the Greater Himalayan Slab are compatible with extrusion models that call for significant components of pure shear deformation. At the top of the slab, our data from the Everest Massif indicate $W_{\mathrm{m}}$ values ranging from 0.67 to 0.98 , depending on structural position and analytical technique used (Fig. 11). These estimated $W_{\mathrm{m}}$ values correspond to pure shear components representing $53-13 \%$ of the total recorded deformation. To date, only one other quantitative vorticity analysis has been made of the Greater Himalayan Slab. In that study Grasemann et al. (1999) used quartz petrofabricstrain data (similar to our Method 3) and flanking folds around tension gashes (see also Grasemann et al. 2003) to quantify vorticity of flow along a basal section of the Greater Himalayan Slab. This section is exposed in the Sutlej Valley of NW India, and located c. $1000 \mathrm{~km}$ along strike to the west of the Everest Massif (Fig. 1). In these Main Central thrust zone rocks $W_{\mathrm{m}}$ values close to simple shear were inferred from the earlier high-temperature petrofabric-strain data, and an increasing component of pure shear deformation $\left(W_{\mathrm{m}}\right.$ c. $\left.0.57-0.71\right)$ was estimated from the later lower-temperature vein data (Grasemann et al. 1999).

However, although these data from the upper and lower surfaces of the Greater Himalayan Slab confirm the operation of a general shear flow associated with south-directed extrusion, they do not allow us to discriminate between currently competing models for general shear flow associated with slab extrusion. For example, is general shear deformation concentrated at the boundaries of the slab or wedge (Grasemann et al. 1999) as implied in channel flow models (Grujic et al. 1996, 2002; Beaumont et al. 2001), or in the hotter interior of the slab; or, for a given cross-section through the slab, does vorticity remain 
fairly constant as assumed in the model of Vannay \& Grasemann (2001)? Testing of these models requires that the spatial and temporal distribution of strain and vorticity domains be mapped out across the slab.

This work was funded by NSF grant EAR 0207524 to R.D.L. and M.P.S., and grants from the Royal Society and the NERC (NER/K/S/2000/951) to M.P.S. We are grateful to S. Morgan for bringing to our attention his modified version of the Kruhl (1998) quartz $c$-axis fabric geothermometer (Fig. 7), and to B. Tikoff for suggesting a method for quantifying relationships between kinematic vorticity number $W_{\mathrm{k}}$ and components of pure and simple shear (Fig. 9). We thank K. Hodges, D. De Paor, C. Simpson, B. Tikoff, R. Tracy and S. Wallis for discussion and advice on various aspects of this project, B. Grasemann, D. Grujic and S. Wallis for their reviews of an earlier version of the manuscript, and the editor R. Strachan for his support. We also thank R. Brice for use of his base camps on the north side of Everest, N. Groves and P. Harris for field assistance, and S. Dhakta, R. Schrama and T. Sherpa for logistical help.

\section{References}

Beaumont, C., Jamieson, R.A., Nguyen, M.H. \& Lee, B. 2001. Himalayan tectonics explained by extrusion of a low-viscosity crustal channel coupled to focused surface denudation. Nature, 414, 738-742.

Bobyarchick, A.R. 1986. The eigenvalues of steady state flow in Mohr space. Tectonophysics, 122, 35-51.

Bouchez, J.-L. \& PÊCHeR, A. 1976. Plasticité du quartz et sens de cisaillement dans les quartzite du grand chevauchement central Himalayen. Bulletin de la Société Géologique de France, 18, 1377-1385

Bouchez, J.-L. \& PÊCher, A. 1981. Himalayan Main Central Thrust pile and its quartz-rich tectonites in central Nepal. Tectonophysics, 78, 23-50.

Brunel, M. 1986. Ductile thrusting in the Himalayas: shear sense criteria and stretching lineations. Tectonics, 5, 247-265.

Brunel, M. \& Kienast, J.-R. 1986. Étude pétro-structurale des chevauchments ductiles himalayens sur la transversale de l'Everest-Makalu (Népal oriental). Canadian Journal of Earth Sciences, 23, 1117-1137.

Burchfiel, B.C., Zhiliang, C., Hodges, K.V., Yuping, L., Royden, L., Changrong, D. \& Jiene, X. 1992. The South Tibetan Detachment System,Himalayan Orogen: Extension Contemporaneous with and Parallel to Shortening in a Collisional Mountain Belt. Geological Society of America, Special Papers, 269.

Burg, J.-P. 1983. Carte Géologique du Sud du Tibet. Ministry of Geology, Beijing, and CNRS, Paris.

Burg, J.-P., Brunel, M., Gapais, D., Chen, G.M. \& Liu, G.H. 1984. Deformation of leucogranites of the crystalline Main Central sheet in southern Tibet (China). Journal of Structural Geology, 6, 535-542.

Carosi, R., Lombardo, B., Molli, G., Musumeci, G. \& Pertusati, P. 1998. The South Tibetan detachment system in the Rongbuk valley, Everest region. Deformation features and geological implications. Journal of Asian Earth Sciences, 16, 299-311.

Catlos, E.J., Harrison, T.M., Manning, C.E., Grove, M., Rai, S.M., Hubbard, M.S. \& Upreti, B.N. 2002. Records of the evolution of the Himalayan orogen from in situ $\mathrm{Th}-\mathrm{Pb}$ microprobe dating of monazite: Eastern Nepal and western Garhwal. Journal of Asian Earth Sciences, 20, 459-479.

Dèzes, P.J., VAnnay, J.-C., Steck, A., Bussy, F. \& Cosca, M. 1999. Synorogenic extension, quantitative constraints on the age and displacement of the Zanskar Shear Zone (northwest Himalaya). Geological Society of America Bulletin, 111, 364-374.

Fitzgerald, J.D. \& Stunitz, H. 1993. Deformation of granitoids at low metamorphic grade. I: Reactions and grain size reduction. Tectonophysics, 221, 269-297.

Fossen, H. \& TiKofF, B. 1998. Forward modeling of non-steady-state deformations and the 'minimum strain path': Reply. Journal of Structural Geology, 20, 979-981.

GANSSER, A. 1964. Geology of the Himalayas. Wiley Interscience, London.

Grasemann, B. \& ManckTelow, N.S. 1993. Two dimensional thermal modeling of normal faulting: the Simplon Fault Zone, Central Alps, Switzerland. Tectonophysics, 225, 155-165.

Grasemann, B., Fritz, H. \& Vannay, J.C. 1999. Quantitative kinematic flow analysis from the Main Central Thrust Zone (NW-Himalaya, India); implications for a decelerating strain path and the extrusion of orogenic wedges. Journal of Structural Geology, 21, 837-853.

Grasemann, B., Stuwe, K. \& Vannay, J.-C. 2003. Sense and non-sense of shear in flanking structures. Journal of Structural Geology, 25, 19-34.
Grujic, D., Casey, M., Davidson, C., Hollister, L., Kundig, K., Pavlis, T. \& Schmid, S. 1996. Ductile extrusion of the Higher Himalayan crystalline in Bhutan: evidence from quartz microfabrics. Tectonophysics, 260, 21-43.

Grujic, D., Hollister, L. \& Parrish, R.R. 2002. Himalayan metamorphic sequence as an orogenic channel: insight from Bhutan. Earth and Planetary Science Letters, 198, 177-191.

Harrison, T.M., Ryerson, J., Le Fort, P., Yin, A., Lovera, O. \& Catlos, E. 1997. A late Miocene-Pliocene origin for the Central Himalayan inverted metamorphism. Earth and Planetary Science Letters, 146, 1-7.

Heilbronner, R. \& Tullis, J. 2002. The effect of static annealing on microstructures and crystallographic preferred orientations of quartzites experimentally deformed in axial compression and shear. In: DE MEer, S., Drury, M.R., De Bresser, J.H.P. \& Pennock, G.M. (eds) Deformation Mechanisms, Rheology and Tectonics: Current Status and Future Perspectives. Geological Society, London, Special Publications, 200, 191-218.

Heron, A.M. 1922. Geological results of the Mount Everest reconnaissance expedition. Geographical Journal, 59, 418-431.

Herren, E. 1987. Zanskar shear zone: northeast-southwest extension within the Higher Himalayas (Ladakh, India). Geology, 15, 409-413.

HiRTh, G. \& Tullis, J. 1992. Dislocation creep regimes in quartz aggregates. Journal of Structural Geology, 14, 145-160.

Hirth, G., Teyssier, C. \& Dunlap, W.J. 2001. An evaluation of quartzite flow laws based on comparisons between experimentally and naturally deformed rocks. International Journal of Earth Sciences, 90, 77-87.

Hodges, K.V. 2000. Tectonics of the Himalaya and southern Tibet from two perspectives. Geological Society of America Bulletin, 112, 324-350.

Hodges, K.V., Parrish, R.R., Housch, T.B., Lux, D.R., Burchfiel, B.C., Royden, L.H. \& CHEN, Z. 1992. Simultaneous Miocene extension and shortening in the Himalayan orogen. Science, 258, 1466-1470.

Hodges, K.V., Parrish, R.R. \& Searle, M.P. 1996. Tectonic evolution of the central Annapurna Range, Nepalese Himalayas. Tectonics, 15, 1264-1291.

Hodges, K.V., Bowring, S., Davidek, K., Hawkins, D. \& Krol, M. 1998. Evidence for rapid displacement on Himalayan normal faults and the importance of tectonic denudation in the evolution of mountain ranges. Geology, 26, 483-486.

Hodges, K.V., Hurtado, J.M. \& Whipple, K.X. 2001. Southward extrusion of Tibetan crust and its effect on Himalayan tectonics. Tectonics, 20, 799-809.

HubBaRd, M.S. \& HARRISON, T.M. 1989. ${ }^{40} \mathrm{Ar} /{ }^{39} \mathrm{Ar}$ age constraints on deformation and metamorphism in the Main Central Thrust Zone and Tibetan Slab, eastern Nepal Himalaya. Tectonics, 8, 865-880.

Jessell, M. \& Lister, G.S. 1990. A simulation of the temperature dependence of quartz fabrics. In: KNIPE, R.J. \& RutTer, E.H. (eds) Deformation Mechanisms, Rheology and Tectonics. Geological Society, London, Special Publications, 54, 353-362.

JIANG, D. 1998. Forward modeling of non-steady-state deformations and the 'minimum strain path': Discussion. Journal of Structural Geology, 20, 975-977.

KanAGAWA, K. 1992. MacStrain 2.4: a QuickBASIC strain analysis program for the Macintosh computer. Department of Earth Sciences, Chiba University, Japan.

KruHL, J.H. 1998. Reply: Prism- and basal-plane parallel subgrain boundaries in quartz: a microstructural geothermobarometer. Journal of Metamorphic Petrology, 16, 142-146.

LAw, R.D. 1990. Crystallographic fabrics: a selective review of their applications to research in structural geology. In: KNIPE, R.J. \& RUTTER, E.H. (eds) Deformation Mechanisms, Rheology and Tectonics. Geological Society, London, Special Publications, 54, 335-352.

Law, R.D., Morgan, S.S., Casey, M., Sylvester, A.G. \& Nyman, M. 1992. The Papoose Flat pluton of eastern California: a re-assessment of its emplacement history in the light of new microstructural and crystallographic fabric observations. Transactions of the Royal Society of Edinburgh: Earth Sciences, 83, 361-375.

Law, R.D., Searle, M.P. \& Simpson, R.L. 2001. Microstructural and quartz petrofabric evidence for strain paths and deformation temperatures, South Tibetan Detachment System, Everest Massif, South Tibet (abstract). Journal of Asian Earth Sciences, 19, 38-39.

Lin, S., JiAnG, D. \& Williams, P.F. 1998. Transpression (or transtension) zones of triclinic symmetry: natural example and theoretical modeling. In: HoLDsworth, R.E., Strachan, R.A. \& Dewey, J.F. (eds) Continental Transpression and Transtensional Tectonics. Geological Society, London, Special Publications, 135, 41-57.

LisLe, R.J. 1985. Geological Strain Analysis, a Manual for the Rf/phi Method. Pergamon, New York.

Lister, G.S. 1977. Crossed-girdle $c$-axis fabrics in quartzites plastically deformed by plane strain and progressive simple shear. Tectonophysics, 39, 51-54.

Lister, G.S. \& Dornsiepen, U.F. 1982. Fabric transitions in the Saxony Granulite Terrain. Journal of Structural Geology, 4, 81-92. 
Lister, G.S. \& Hobbs, B.E. 1980. The simulation of fabric development during plastic deformation and its application to quartzite: fabric transitions. Journal of Structural Geology, 1, 99-115.

Lombard, A. 1958. Un Itineraire Géologique dans l'Est du Nepal (Massif du Mont Everest). Mémoires de la Société Helvetique des Sciences Naturelles, 82.

Lombardo, B., Pertusati, P. \& Borgi, S. 1993. Geology and tectonomagmatic evolution of the eastern Himalaya along the Chomolungma-Makalu transect. In: Treloar, P.J. \& Searle, M.P. (eds) Himalayan Tectonics. Geological Society, London, Special Publications, 74, 341-355.

Means, W.D. 1989. Stretching faults. Geology, 17, 893-896.

MEans, W.D. 1994. Rotational quantities in homogeneous flow and the development of small-scale structures. Journal of Structural Geology, 16, 437-446.

Means, W.D., Hobbs, B.E., Lister, G.S. \& Williams, P.F. 1980. Vorticity and non-coaxiality in progressive deformations. Journal of Structural Geology, 2, 371-378.

Murphy, M.A. \& HARrison, T.M. 1999. Relationship between leucogranites and the Qomolangma Detachment in the Rongbuk valley, south Tibet. Geology, 27, 831-834.

Nyman, M.W., Law, R.D. \& Morgan, S.S. 1995. Conditions of contact metamorphism, Papoose Flat Pluton, eastern California, USA: implications for cooling and strain histories. Journal of Metamorphic Geology, 13, $627-643$.

OdELL, N.E. 1925. Observations on the rocks and glaciers of Mount Everest. Geographical Journal, 66, 289-315.

ODELL, N.E. 1948. Geological and some other observations in the Mount Everest region. In: Tilman, H.W. (ed.) Mount Everest 1938. Cambridge University Press, Cambridge, 143-154.

Okudaira, T., Takeshita, T., Hara, I. \& Ando, J. 1995. A new estimate of the conditions for transition from basal $\langle\mathrm{a}\rangle$ to prism [c] slip in naturally deformed quartz. Tectonophysics, 250, 31-46.

PAsschier, C.W. 1987. Stable positions of rigid objects in non-coaxial flow-a study in vorticity analysis. Journal of Structural Geology, 9, 679-690.

PAsschier, C.W. 1988. Analysis of deformation paths in shear zones. Geologisches Rundschau, 77, 309-318.

Passchier, C.W. 1998. Monoclinic model shear zones. Journal of Structural Geology, 20, 1121-1138.

Pfiffner, A. \& RAMSAy, J.G. 1982. Constraints on geological strain rates, arguments from finite strain states of naturally deformed rocks. Journal of Geophysical Research, 87, 311-321.

Pognante, U. 1993. Different $P-T-t$ paths and leucogranite occurrences among the High Himalayan Crystallines: implications for subduction and collision along the northern Indian margin. Geodinamica Acta, 6, 5-17.

Pognante, U. \& Benna, P. 1993. Metamorphic zonation, migmatization and leucogranites along the Everest transect of eastern Nepal and Tibet: record of an exhumation history. In: Treloar, P.J. \& Searle, M.P. (eds) Himalayan Tectonics. Geological Society, London, Special Publications, 74, 323-340.

Rowley, D.B. 1998. Minimum age of initiation of collision between India and Asia north of Everest based on subsidence history of the Zhepure mountain section. Journal of Geology, 106, 229-235.

Schmid, S.M. \& CASEY, M. 1986. Complete fabric analysis of some commonly observed quartz c-axis patterns. In: HoBBs, B.E. \& HEARD, H.C. (eds) Mineral and Rock Deformation Laboratory Studies: The Paterson Volume. Geophysical Monograph, American Geophysical Union, 36, 263-286.

SEARLE, M.P. 1996. Cooling history, erosion, exhumation and kinematics of the Himalayan-Karakorum-Tibet orogenic belt. In: YIN, A.N. \& HARRISON, T.M. (eds) The Tectonic Evolution of Asia. Cambridge University Press, Cambridge, 110-137.

SEARLE, M.P. 1999a. Extensional and compressional faults in the Everest-Lhotse massif, Khumbu Himalaya, Nepal. Journal of the Geological Society, London, 156, 227-240.

SEARLE, M.P. 1999b. Emplacement of Himalayan leucogranites by magma injection along giant sill complexes: examples from the Cho Oyu, Gyachung Kang and Everest leucogranites (Nepal Himalaya). Journal of Asian Earth Sciences, 17, 773-783.

SeArle, M.P. 2003. Geological Map of the Mount Everest Region, Nepal and South Tibet; scale 1:50 000. Department of Earth Sciences, Oxford University.

Searle, M.P., Windley, B.F. \& Coward, M.P. ET AL. 1987. The closing of Tethys and tectonics of the Himalaya. Geological Society of America Bulletin, 98, 678-701.

Searle, M.P., Waters, D.J., Dransfield, M.W., Stephenson, B.J., Walker, C.B., Walker, J.D. \& Rex, D.C. 1999. Thermal and mechanical models for the structural evolution of Zanskar High Himalaya. In: MAC Niocaill, C. \& Ryan, P.D. (eds) Continental Tectonics. Geological Society, London, Special Publications, 164, 139-156.

Searle, M.P., Simpson, R.R., Law, R.D., Waters, D.J. \& PARrish, R.R. 2002.
Quantifying displacement on the South Tibetan Detachment normal fault, Everest massif, and the timing of crustal thickening and uplift in the Himalaya and Tibet. Journal of the Nepal Geological Society, 26, 1-6.

Searle, M.P., Simpson, R.R., Law, R.D., Parrish, R.R. \& Waters, D.J. 2003. The structural geometry, metamorphic and magmatic evolution of the Everest massif, High Himalaya of Nepal-South Tibet. Journal of the Geological Society, London, 160, 344-366.

Shimamoto, T. \& Ikeda, Y. 1976. A simple algebraic method for strain estimation from deformed ellipsoidal objects. Tectonophysics, 36, 315-317.

Simpson, C. \& De PAor, D.G. 1993. Strain and kinematic analysis in general shear zones. Journal of Structural Geology, 15, 1-20.

Simpson, C. \& De PAOR, D.G. 1997. Practical analysis of general shear zones using porphyroclast hyperbolic distribution method: an example from the Scandinavian Caledonides. In: Sengupta, S. (ed.) Evolution of Geological Structures in Micro- to Macro-scales. Chapman and Hall, London, 169-184.

Simpson, R.L., Parrish, R.R., Searle, M.P. \& Waters, D.J. 2000. Two episodes of monazite crystallization during metamorphism and crustal melting in the Everest region of the Nepalese Himalaya. Geology, 28, 403-406.

Stephenson, B.J., Searle, M.P. \& Waters, D.J. 2001. Structure of the Main Central Thrust zone and extrusion of the High Himalayan crustal wedge, Kishtwar-Zanskar Himalaya. Journal of the Geological Society, London, 158, $637-652$.

Stipp, M., Stunitz, H., Heilbronner, R. \& Schmid, S. 2002. Dynamic recrystallization of quartz: correlation between natural and experimental conditions. In: De Meer, S., Drury, M.R., De Bresser, J.H.P. \& Pennock, G.M. (eds) Deformation Mechanisms, Rheology and Tectonics: Current Status and Future Perspectives. Geological Society, London, Special Publications, 200, 171-190.

Takeshita, T., Wenk, H.R. \& Lebensohn, R. 1999. Development of preferred orientation and microstructure in sheared quartzite: comparison of natural data and simulated results. Tectonophysics, 312, 133-155.

Thompson, A.B., Schulman, K. \& JezeK, J. 1997. Thermal evolution and exhumation in obliquely convergent (transpressive) orogens. Tectonophysics, 280, 171-184.

Tikoff, B. \& Teyssier, C. 1994. Strain and fabric analysis based on porphyroclast interaction. Journal of Structural Geology, 16, 477-492.

Tullis, J. 1977. Preferred orientation of quartz produced by slip during plane strain. Tectonophysics, 39, 87-102.

Tullis, J.A. \& Yund, R.A. 1992. The brittle-ductile transition in feldspar aggregates: an experimental study. In: Evans, B. \& Wong, T.F. (eds) Fault Mechanics and Transport Properties of Rocks. Academic Press, London, 89-117.

Tullis, J.A., Christie, J.M. \& Griggs, D.T. 1973. Microstructures and preferred orientations of experimentally deformed quartzites. Geological Society of America Bulletin, 84, 297-314.

VAnNAy, J.-C. \& Grasemann, B. 2001. Himalayan inverted metamorphism and syn-convergence extension as a consequence of a general shear extrusion. Geological Magazine, 138, 253-276.

Villa, I., Tonarini, S. \& Lombardo, B. 1998. $\mathrm{Rb} / \mathrm{Sr}$ and $\mathrm{Ar} / \mathrm{Ar}$ ages of muscovites from leucogranites of the Chomolungma-Cho Oyu region, southern Tibet. Geological Bulletin, University of Peshawar, 31, 1203-1204.

WAGER, L.R. 1934. A review of the geology and some new observations. In: Ruttledge, H. (ed.) Everest 1933. Hodder \& Stoughton, London, 312-336.

WAGER, L.R. 1965. Injected granite sheets of the Rongbuk valley and the north face of Mount Everest. In: D. N. Wadia Commemorative Volume. India Mining, Geology and Metallurgy Institute, 358-379.

Walker, J.D., Martin, M.W., Bowring, S.A., Searle, M.P., Waters, D.J. \& HodGES, K.V. 1999. Metamorphism, melting, and extension: age constraints from the High Himalayan slab of southeast Zanskar and northwest Lahaul. Journal of Geology, 107, 473-495.

WALLIS, S.R. 1992. Vorticity analysis in a metachert from the Sanbagawa Belt, SW Japan. Journal of Structural Geology, 14, 271-280.

WALLIS, S.R. 1995. Vorticity analysis and recognition of ductile extension in the Sanbagawa belt, SW Japan. Journal of Structural Geology, 17, 1077-1093.

Wallis, S.R., Platt, J.P. \& KNotT, S.D. 1993. Recognition of syn-convergence extension in accretionary wedges with examples from the Calabrian Arc and the Eastern Alps. American Journal of Science, 293, 463-495.

WANG, Z. \& ZHEN, X. 1975. Imbricate structure in the northern slope of Jolmo Lungma and discussion on the uplift of the Himalaya. In: Scientific Exploration of Jolmo Lungma. Science Publishing House, Beijing, 199-221.

Xypolias, P. \& Koukouvelas, I.K. 2001. Kinematic vorticity and strain patterns associated with ductile extrusion in the Chelmos shear zone (External Hellenides, Greece). Tectonophysics, 338, 59-77.

YIN, C.H. \& Kuo, S.T. 1978. Stratigraphy of the Mount Jolmo Lungma and its north slope. Scientia Sinica, 21, 629-644. 